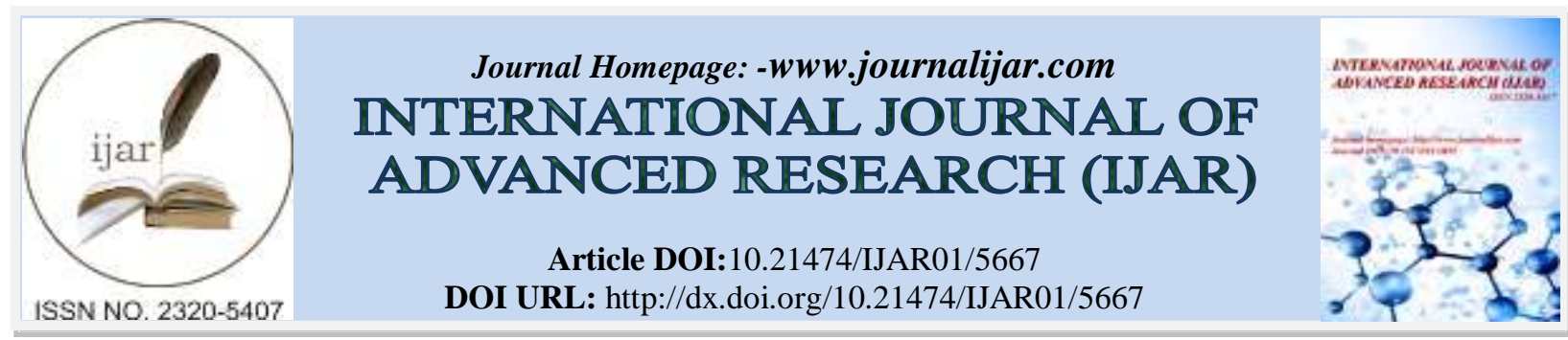

RESEARCH ARTICLE

\title{
INDO-RUSSIA ECONOMIC TIES WITH ASEAN VIS-À-VIS OTHER REGIONAL ORGANIZATIONS OF THE WORLD.
}

\author{
Prachi Madhumita Mohanty ${ }^{1}$, Prof. S.S.Acharya ${ }^{2}$ and Dr. Gitanjali Panda ${ }^{3}$. \\ 1. PrachiMadhumitaMohanty, ICSSR Doctoral Fellow,Dept.of Social Science, F.M.University. \\ 2. Dr. S.S.Acharya, Retd. Professor of Political Science, F.M.University. \\ 3. Dr. Gitanjali Panda, Asst. Prof in Economics, F.M.University, Balasore,Odisha.
}

\section{Manuscript Info}

Manuscript History

Received: 19 August 2017

Final Accepted: 21 September 2017

Published: October 2017

\begin{abstract}
The present Russia which has stepped in to the shoes of former USSR continues to be consistent friend of India. The then USSR rescued India in many a crisis situation. In this post cold war globalised world they continue to be major trade partners. In certain regional organizations like ASEAN they are found to reinforce each other's trade interests. In the post-cold war scenario both the powers have evinced interest in promoting economic relations with SEA countries. Both of them are active in other regional economic organizations like SAARC, APEC, BRICS \& EU. A comparative picture of their trade relations with these organizations vis-à-vis ASEAN has been presented. This article is a part of the dissertation being prepared for the doctoral research on "Indo-Russia Cooperation in SEA: Move towards multipolar world". This intends to throw adequate light on the trading status of India with SEA in conformity with the Act East Policy enunciated by the present prime-minister and cooperation with another resurgent power i.e Russia in this matter.
\end{abstract}

Copy Right, IJAR, 2017,. All rights reserved.

\section{Introduction:-}

With the end of the cold war the world scenario changed and world moved from bipolarity to unipolarity under the leading role of US. The dominant role of US only was retained in every sphere like military, economy, politics, culture etc. Economically emerging countries like China, India i.e. the great powers tried to develop further and Russia also began its quest of its earlier position in the newly unfolding system of international relations. During the cold war period, politically Southeast Asia and India were on different sides with most of the Southeast Asian states being anti-communists while India sided with the then USSR. ASEAN (Association of South East Asian Nations) also hesitated to support India's proposed security arrangement in the region before, primarily because it was seen as the Soviet Union's move in asserting its influence over the region. (Wayfarer 2007) Though Indo-Russia relations stagnated sometime in the era of globalization, still India and Russia's relations can't be characterized as vulnerable at any point of time. But here the objective of this paper is to show how Indo-Russia Cooperation in SEA (South East Asian) Countries is much effective in the emerging International system. The main aim is to find out trade relation of India and Russia especially with South East Asia and the potentialities of ASEAN in holding prospects for more trade with both India and Russia. 


\section{Methodology:-}

This study is the result of a doctoral work carried on "Indo-Russia Cooperation in South East Asia: Move towards Multipolar world". Examining the data relating to trade between India, Russia and ASEAN constitutes the major obligation of this research. It tries to discern some of the trends of exports among India \& Russia with ASEAN in comparison to other organizations over the years during the period 2001-16. The growth rate of exports is also focused in this piece of research. Therefore, this research heavily depends upon the data available from UNCOMTRADE, Indian Trade Portal Ministry of External Affairs, and India. The analysis of articles of journals, books, and news papers has constituted the core of it.

\section{South East Asian Nations and Formation of ASEAN:-}

Southeast Asia consists of the countries that are geographically south of China, east of India, west of New Guinea and north of Australia. It is a sub region of Asia and also divided into two sub regions, that is Mainland Southeast Asia (or Indo-china) and Maritime Southeast Asia. Mainland Southeast Asia comprises six states i.e. Vietnam, Laos, Cambodia, Thailand, Myanmar (Burma), Peninsular Malaysia and Maritime Southeast Asia includes five states i.e. Indonesia, Philippines, Brunei, Singapore, East Timor and part of the Malaysia i.e. East Malaysia. All of the nations are member of the ASEAN, as East Timor is an observer state. Trade relation or economic cooperation among Southeast Asian states has a long custom. The impact of colonial rule, struggle for independence and in some cases war influenced the economic attitudes and policies of those SEA nations.(Baten,2016)The purpose of formation of ASEAN is to accelerate the economic growth, social progress and cultural development in the region through joint endeavors in the spirit of equality and partnership in order to strengthen the foundation for a prosperous and peaceful community of SEA nations. ASEAN provides a forum for the integration of commerce, and regional responses to international concerns. Though geographically Indonesia is the largest country in Southeast Asian region, all the major five South East Asian nations; Singapore, Malaysia, Indonesia, the Philippines and Thailand have socio-economic importance and cultural legacy of their own. If we take ASEAN as a single unit, it would rank as the sixth largest economy in the world, behind USA, China, Japan, India and Germany. ASEAN shares land borders with India, China, Bangladesh, East Timor, and Papua New Guinea, and maritime borders with India, China, Palau, and Australia. Both East Timor and Papua New Guinea are backed by certain ASEAN members for their membership in the organization. ASEAN has been establishing itself as a platform for Asian integration and cooperation, working with other Asian nations to promote unity, prosperity, development and sustainability of the region, as well as working on solutions to resolve disputes and problems in the region. While mainly focusing on the Asia-Pacific nations, ASEAN also establishes communications with other parts of the world, to better promote world peace and stability. The organization has a global reputation of promoting goodwill and diplomacy among nations, shutting out any biased opinion or decision, and carrying the principle of non-Interference. In its onward journey ASEAN has strengthened partnership with external partners, including Dialogue Partners, multilateral development banks, international organizations and others for effective and efficient implementation of the Master Plan on ASEAN connectivity. The Master Plan ensures the synchronization of ongoing sectoral strategies and plans within the frameworks of ASEAN and its sub-regions. Through an enhanced ASEAN Connectivity, the production and distribution networks in the ASEAN region will be deepened, widened, and get more entrenched in the East Asia and global economy. Beyond the region, ASEAN needs to collectively respond to the opportunities offered by its geographical and comparative advantages and to the competitive challenges brought about by global trade and investment environment. ASEAN is located at the center of an economically vibrant and growing region bounded by India in the West; China, Japan and the Republic of Korea in the Northeast; and Australia and New Zealand in the South. In this master plan one figure also brought out a comparison among ASEAN-China, ASEAN-India, and Intra-ASEAN trade. But this study only highlights ASEAN-India trade. There is an additional challenge for the ASEAN region, arising from its success in plugging into the fast growing Chinese and Indian economies, which would draw the importance of ASEAN Connectivity. Specifically, ASEAN-India trade has picked up tremendous steam since 2004, also growing at 24 percent per annum during 2004-2009; although the ratio of ASEAN-India trade to the total intra-ASEAN trade was just at 11 percent by 2009. In the light of the recent trends in ASEAN-India trade, intra-ASEAN trade needs to grow at least in step with ASEAN-China trade to reinforce ASEAN's centrality and its role as the driving force in regional integration.(Master plan, 2010)

\section{India \& ASEAN:-}

India's interest to strengthen multi-faceted relationship with ASEAN is a consequence of the major changes in the world's political and economic scenario since the early 1990s. India and ASEAN are natural partners due to geographical proximity and tradition of cultural interaction. However the economic crisis of 1991 along with the collapse of the Soviet Union, India's only economic and strategic partner, the end of the Cold War and the onset of 
globalization made India realize that the best means for development would come through promotion of international trade and attracting foreign investments. India's own march towards economic liberalization is search for economic space resulted in the 'Look East Policy', which is an economic policy of engagement with Southeast Asia as an official initiative in achieving two objectives: the encouragement of trade links with individual partners and to provide foreign employment for India's own expanding work force. In the recent times India's foreign policy towards South East Asia has got a much added boost in International sphere. The Look East Policy has boost up into a vibrant as 'Act East Policy'. Prime Minister Narendra Modi at the 12th ASEAN India Summit and the 9th East Asia Summit held in Nay Pyi Taw, Myanmar, in November, 2014, formally enunciated the Act East Policy. (MEA,2014)Due to the assertive rise of China, Act East Policy (AEP) has imparted greater vigor to India's ties with ASEAN. In particular, India has accorded a new focus on promoting connectivity through Myanmar and Thailand with other ASEAN states. Modi's allocation of $\$ 1$ billion for promoting connectivity at the India-ASEAN Summit in KualaLumpur last November has brought the primacy of "connectivity, culture, and commerce" to the fore. India has recognized that success of AEP will be determined by its contribution to security and economic development of Northeast India. AEP has sought to significantly expand its geographical coverage beyond ASEAN alone, to include other countries like Japan, Australia, Pacific Island nations, South Korea, and Mongolia. (Sajjanhar,2016)From a Look East to Act East perspective, it might be useful to recall a bit of past of India and ASEAN relationship. India's interaction has started as a sectoral dialogue partner of ASEAN in 1992 on areas such as trade, investment, tourism and science and technology. Mutual interest for a wider engagement was the main interest of India and ASEAN. India was invited as a full dialogue partner of ASEAN during the Fifth ASEAN Summit in Bangkok in December 1995. The implication of India for Asia's regional security prompted ASEAN also to invite India to be a member of the ASEAN Regional Forum (ARF) in July 1996. However, the most important milestone was achieved with the hosting of the first ASEAN India summit in Phnom Penh, Cambodia during November 2002, which came as a result of strong signals of economic co-operation from India provided by a series of bilateral visits by Indian leaders to existing as well as smaller and newer members of ASEAN. (Heng, Wei-Yen,2004)

During the period of Modi's foreign policy, neighborhood got added priority and a renewed desire to make India emerge a global power got a concrete shape. This found expression in pursuing a vigorous trade policy with different regional organizations including ASEAN. Table-I is basically focused on India and ASEAN trade relations expressed in terms of exports and imports during 2001-1016. This is analyzed in terms of percentage of India's exports to and import from ASEAN in proportion to its total exports to and imports from the world. Table-I reflects India's exports to and imports from the world as well as to ASEAN and the exports to and imports from ASEAN as a proportion of total exports to and imports from the world, expressed in terms of percentage.

Table-I :-India's Export And Import To ASEAN And World During The Period 2001-2016. Unit-Thousand USD

\begin{tabular}{|c|c|c|c|c|c|c|c|}
\hline INDIA'S & EXPORT & TO & ASEAN & INDIA'S & IMPORT & FROM ASEAN & Trade \\
\hline YEAR & World & ASEAN & Percentage & World & ASEAN & Percentage & Balance \\
\hline $\mathbf{2 0 0 1}$ & 43878489 & 3315112 & $\mathbf{7 . 6 \%}$ & 50671106 & 4345489 & $\mathbf{8 . 6 \%}$ & 2726966 \\
\hline $\mathbf{2 0 0 2}$ & 50097958 & 4503303 & $\mathbf{9 . 0 \%}$ & 57453469 & 4807277 & $\mathbf{8 . 4 \%}$ & 2508544 \\
\hline $\mathbf{2 0 0 3}$ & 59360659 & 5071800 & $\mathbf{8 . 5 \%}$ & 72430524 & 6686881 & $\mathbf{9 . 2 \%}$ & 4045337 \\
\hline $\mathbf{2 0 0 4}$ & 75904200 & 7552218 & $\mathbf{9 . 9 \%}$ & 98981129 & 8549995 & $\mathbf{8 . 6 \%}$ & 3858889 \\
\hline $\mathbf{2 0 0 5}$ & 100352637 & 10285769 & $\mathbf{1 0 . 2 \%}$ & 140861667 & 10632023 & $\mathbf{7 . 5 \%}$ & 6529817 \\
\hline $\mathbf{2 0 0 6}$ & 121200606 & 12369341 & $\mathbf{1 0 . 2 \%}$ & 178212440 & 16300608 & $\mathbf{9 . 1 \%}$ & 8610758 \\
\hline $\mathbf{2 0 0 7}$ & 145898053 & 13824081 & $\mathbf{9 . 5 \%}$ & 218645294 & 21031035 & $\mathbf{9 . 6 \%}$ & 11440221 \\
\hline $\mathbf{2 0 0 8}$ & 181860898 & 19433467 & $\mathbf{1 0 . 7 \%}$ & 315712106 & 26698438 & $\mathbf{8 . 5 \%}$ & 11554719 \\
\hline $\mathbf{2 0 0 9}$ & 176765036 & 17898835 & $\mathbf{1 0 . 1 \%}$ & 266401553 & 23968100 & $\mathbf{9 . 0 \%}$ & 12905730 \\
\hline $\mathbf{2 0 1 0}$ & 220408496 & 22958453 & $\mathbf{1 0 . 4 \%}$ & 350029387 & 29640182 & $\mathbf{8 . 5 \%}$ & 17171964 \\
\hline $\mathbf{2 0 1 1}$ & 301483250 & 34497614 & $\mathbf{1 1 . 4 \%}$ & 462402791 & 40331863 & $\mathbf{8 . 7 \%}$ & 17641513 \\
\hline $\mathbf{2 0 1 2}$ & 289564769 & 32295000 & $\mathbf{1 1 . 2 \%}$ & 488976378 & 42737956 & $\mathbf{8 . 7 \%}$ & 15240679 \\
\hline $\mathbf{2 0 1 3}$ & 336611389 & 37885468 & $\mathbf{1 1 . 3 \%}$ & 466045567 & 42308784 & $\mathbf{9 . 1 \%}$ & 16254131 \\
\hline $\mathbf{2 0 1 4}$ & 317544642 & 31294246 & $\mathbf{9 . 9 \%}$ & 459369464 & 44457579 & $\mathbf{9 . 7 \%}$ & 19370039 \\
\hline $\mathbf{2 0 1 5}$ & 264381004 & 26428121 & $\mathbf{1 0 . 0 \%}$ & 390744731 & 41516394 & $\mathbf{1 0 . 6 \%}$ & 20258259 \\
\hline $\mathbf{2 0 1 6}$ & 260326912 & 26381170 & $\mathbf{1 0 . 1 \%}$ & 356704792 & 38222455 & $\mathbf{1 0 . 7 \%}$ & 13757880 \\
\hline CAGR & $\mathbf{1 4 . 7 1 \%}$ & $\mathbf{1 6 . 3 9 \%}$ & & $\mathbf{1 6 . 3 8 \%}$ & $\mathbf{1 7 . 7 4 \%}$ & & \\
\hline
\end{tabular}

Source-http://www.trademap.org/stdatasources:- 
India's exports to the ASEAN in proportion to the world exports has increased from $7.6 \%$ in 2001 to $11.4 \%$ in 2011 and it has declined in recent years to $10.1 \%$ in 2016, whereas India's imports from ASEAN in proportion to India's total imports from the world have increased from $8.6 \%$ in 2001 to $10.7 \%$ in 2016.The compound annual growth rate of exports to and imports from ASEAN have increased at $16.39 \%$ and $17.74 \%$ respectively and which is more than that of the trade relation with the world. The figures of trade balance indicate India is having favorable trade balance with ASEAN. The size of the positive trade balance has increased over the study period with some fluctuations. The trend of exports and imports between India and ASEAN countries reflects increasing trade openness in the last fifteen years.

In 2001 India's export to ASEAN was 7.6\% and at the same time India's import from ASEAN was 8.6\%. But since 2002 the India's export to ASEAN was $9.0 \%$ of exports to total world which was higher compared to imports. India's export to ASEAN touched the highest value ever during 2011-13 i.e 11.4\%. After that till 2016 it was little bit on decline and touched $10.1 \%$ in 2016. It is to be noted that ASEAN is India's fourth largest trading partner. India became the third dialogue partner of ASEAN to set off an ASEAN Connectivity Coordinating CommitteeIndia Meeting. While India has made extensive progress in implementing the India-Myanmar-Thailand Trilateral Highway and the Kaladan Multimodal Project, issues related to increasing the maritime and air connectivity between ASEAN and India. One important thing is that export percentage is higher than import during the years 2002, 2004, 2005, and 2006, 2008-2014.In 2015 \& 2016 India's Import from ASEAN has increased in comparison with India's export to ASEAN.

\section{India's export to various ASEAN Nations:-}

History must reveal that the ASEAN's engagement with India has seen some important milestones for deepening economic and political relations ever since the end of the Cold War and India's determined pursuit of a Look East Policy since 1991, which has already been focused previously. ASEAN India trade picked up momentum in the nineties barring the East Asian crisis period. Recent years witnessed the growth of trade between them at double digit rate. The inherent potential of this trade is revealed in rising India's exports to the region and the necessity felt to investigate the gains achieved in the process of building of the economic relations between the two. IndiaASEAN engagements at the summit level and all the ensuing developments have helped India to become a credible interlocutor with the major powers of the world. Singapore is the one which inked maximum number of regional agreements, where India, Singapore and Thailand are involved in maximum number of regional agreements in Asia. (Choudhary,2013) India's reciprocity in 1994 is marked through the joint anti-submarine warfare exercises. A two pronged strategy adopted by Singapore and India has intensified their relations. It assumed the forms of defence cooperation Agreement in 2003 and the subsequent Comprehensive Economic Cooperation Agreement (CECA). The secretary level dialogues followed the defence cooperation agreement. Singapore and India conducted first (SINDEX 04) and second bilateral air exercises at Gwalior5 in 2004 and Kalaikunda near Kolkata in January 2006 respectively. In 2004, Singapore was granted training facilities for its army and air force on Indian soil. This marked an unprecedented step for India which usually avoided foreign military presence of any type on its territory. Joint naval exercise with Singapore was also undertaken in South China SEA in 2005.The Indian defence production network is all set to cater to the needs of Malaysia for its defence modernization programme, Malaysia also sought help of India in the training of the Sukhoi pilots and industrial cooperation of Hindustan Aeronautics limited. (Jha, 2011)

Table II outlines the share of individual member countries of ASEAN in India's Exports to ASEAN for the period under study. It has been made clear that all south East Asian nations are members of ASEAN except one nation i.e. Timor.

Table-II:-India's export to various ASEAN Nations and the growth rate during 2001-16

Unit-Thousand USD

\begin{tabular}{|l|l|l|l|l|l|l|l|l|l|l|l|}
\hline & $\begin{array}{l}\text { ASEA } \\
\text { N }\end{array}$ & $\begin{array}{l}\text { Singap } \\
\text { ore }\end{array}$ & $\begin{array}{l}\text { Viet } \\
\text { Nam }\end{array}$ & $\begin{array}{l}\text { Malay } \\
\text { sia }\end{array}$ & $\begin{array}{l}\text { Indon } \\
\text { esia }\end{array}$ & $\begin{array}{l}\text { Thail } \\
\text { and }\end{array}$ & $\begin{array}{l}\text { Philippi } \\
\text { nes }\end{array}$ & $\begin{array}{l}\text { Myan } \\
\text { mar }\end{array}$ & $\begin{array}{l}\text { Cambo } \\
\text { dia }\end{array}$ & $\begin{array}{l}\text { Brunei } \\
\text { Darussa } \\
\text { lam }\end{array}$ & Lao \\
\hline 2001 & 33151 & 926002 & 21796 & 78812 & 47677 & 59829 & 231773 & 57658 & 10545 & 2210 & 5765 \\
& 12 & $(27.93$ & 4 & 5 & 9 & 1 & $(6.99 \%)$ & $(1.74 \%$ & $(0.32 \%$ & $(0.07 \%)$ & $\begin{array}{l}(0.17 \\
\%)\end{array}$ \\
& $\%)$ & $\begin{array}{l}(6.57 \\
\%)\end{array}$ & $\begin{array}{l}(23.77 \\
\%)\end{array}$ & $\begin{array}{l}(14.38 \\
\%)\end{array}$ & $\begin{array}{l}(18.05 \\
\%)\end{array}$ & & ) & ) & & & \\
\hline
\end{tabular}




\begin{tabular}{|c|c|c|c|c|c|c|c|c|c|c|c|}
\hline 2002 & $\begin{array}{l}45033 \\
03\end{array}$ & $\begin{array}{l}138039 \\
4 \\
(30.65 \\
\%)\end{array}$ & $\begin{array}{l}30444 \\
1 \\
(6.76 \\
\%)\end{array}$ & $\begin{array}{l}74278 \\
7 \\
(16.49 \\
\%)\end{array}$ & $\begin{array}{l}76961 \\
2 \\
(17.09 \\
\%)\end{array}$ & $\begin{array}{l}74118 \\
3 \\
(16.46 \\
\%)\end{array}$ & $\begin{array}{l}467306 \\
(10.38 \\
\%)\end{array}$ & $\begin{array}{l}73939 \\
(1.64 \% \\
)\end{array}$ & $\begin{array}{l}16969 \\
(0.38 \% \\
)\end{array}$ & $\begin{array}{l}4649 \\
(0.10 \%)\end{array}$ & $\begin{array}{l}2023 \\
(0.04 \\
\%)\end{array}$ \\
\hline 2003 & $\begin{array}{l}50718 \\
00\end{array}$ & $\begin{array}{l}170190 \\
5 \\
(33.56 \\
\%)\end{array}$ & $\begin{array}{l}37884 \\
1 \\
(7.47 \\
\%)\end{array}$ & $\begin{array}{l}79308 \\
7 \\
(15.64 \\
\%)\end{array}$ & $\begin{array}{l}10396 \\
15 \\
(20.50 \\
\%)\end{array}$ & $\begin{array}{l}73177 \\
2 \\
(14.43 \\
\%)\end{array}$ & $\begin{array}{l}324317 \\
(6.39 \%)\end{array}$ & $\begin{array}{l}76612 \\
(1.51 \% \\
)\end{array}$ & $\begin{array}{l}20270 \\
(0.40 \% \\
)\end{array}$ & $\begin{array}{l}4863 \\
(0.10 \%)\end{array}$ & $\begin{array}{l}518 \\
(0.01 \\
\%)\end{array}$ \\
\hline 2004 & $\begin{array}{l}75522 \\
18\end{array}$ & $\begin{array}{l}341645 \\
9 \\
(45.24 \\
\%)\end{array}$ & $\begin{array}{l}53484 \\
6 \\
(7.08 \\
\%)\end{array}$ & $\begin{array}{l}10402 \\
07 \\
(13.77 \\
\%)\end{array}$ & $\begin{array}{l}12055 \\
94 \\
(15.96 \\
\%)\end{array}$ & $\begin{array}{l}85682 \\
8 \\
(11.35 \\
\%)\end{array}$ & $\begin{array}{l}362923 \\
(4.81 \%)\end{array}$ & $\begin{array}{l}112698 \\
(1.49 \% \\
)\end{array}$ & $\begin{array}{l}16754 \\
(0.22 \% \\
)\end{array}$ & $\begin{array}{l}4956 \\
(0.07 \%)\end{array}$ & $\begin{array}{l}953 \\
(0.01 \\
\%)\end{array}$ \\
\hline 2005 & $\begin{array}{l}10285 \\
769\end{array}$ & $\begin{array}{l}542755 \\
5 \\
(52.77 \\
\%)\end{array}$ & $\begin{array}{l}63346 \\
5 \\
(6.16 \\
\%)\end{array}$ & $\begin{array}{l}11437 \\
75 \\
(11.12 \\
\%)\end{array}$ & $\begin{array}{l}13900 \\
66 \\
(13.51 \\
\%)\end{array}$ & $\begin{array}{l}10592 \\
67 \\
(10.30 \\
\%)\end{array}$ & $\begin{array}{l}482110 \\
(4.69 \%)\end{array}$ & $\begin{array}{l}117246 \\
(1.14 \% \\
)\end{array}$ & $\begin{array}{l}21350 \\
(0.21 \% \\
)\end{array}$ & $\begin{array}{l}4395 \\
(0.04 \%)\end{array}$ & $\begin{array}{l}6540 \\
(0.06 \\
\%)\end{array}$ \\
\hline 2006 & $\begin{array}{l}12369 \\
341\end{array}$ & $\begin{array}{l}612725 \\
0 \\
(49.54 \\
\%)\end{array}$ & $\begin{array}{l}87409 \\
8 \\
(7.07 \\
\%)\end{array}$ & $\begin{array}{l}13313 \\
65 \\
(10.76 \\
\%)\end{array}$ & $\begin{array}{l}18698 \\
06 \\
(15.12 \\
\%)\end{array}$ & $\begin{array}{l}13509 \\
85 \\
(10.92 \\
\%)\end{array}$ & $\begin{array}{l}596836 \\
(4.83 \%)\end{array}$ & $\begin{array}{l}124088 \\
(1.00 \% \\
)\end{array}$ & $\begin{array}{l}48089 \\
(0.39 \% \\
)\end{array}$ & $\begin{array}{l}44462 \\
(0.36 \%)\end{array}$ & $\begin{array}{l}2362 \\
(0.02 \\
\%)\end{array}$ \\
\hline 2007 & $\begin{array}{l}13824 \\
081\end{array}$ & $\begin{array}{l}639006 \\
8 \\
(46.22 \\
\%) \\
\end{array}$ & $\begin{array}{l}12414 \\
77 \\
(8.98 \\
\%)\end{array}$ & $\begin{array}{l}18502 \\
54 \\
(13.38 \\
\%)\end{array}$ & $\begin{array}{l}18781 \\
96 \\
(13.59 \\
\%)\end{array}$ & $\begin{array}{l}16733 \\
37 \\
(12.10 \\
\%)\end{array}$ & $\begin{array}{l}571413 \\
(4.13 \%)\end{array}$ & $\begin{array}{l}162757 \\
(1.18 \% \\
)\end{array}$ & $\begin{array}{l}44826 \\
(0.32 \% \\
)\end{array}$ & $\begin{array}{l}8814 \\
(0.06 \%)\end{array}$ & $\begin{array}{l}2939 \\
(0.02 \\
\%)\end{array}$ \\
\hline 2008 & $\begin{array}{l}19433 \\
467\end{array}$ & $\begin{array}{l}885390 \\
0 \\
(45.56 \\
\%)\end{array}$ & $\begin{array}{l}18126 \\
07 \\
(9.33 \\
\%)\end{array}$ & $\begin{array}{l}30344 \\
08 \\
(15.61 \\
\%)\end{array}$ & $\begin{array}{l}26593 \\
14 \\
(13.68 \\
\%)\end{array}$ & $\begin{array}{l}20052 \\
80 \\
(10.32 \\
\%)\end{array}$ & $\begin{array}{l}755025 \\
(3.89 \%)\end{array}$ & $\begin{array}{l}237333 \\
(1.22 \% \\
)\end{array}$ & $\begin{array}{l}53854 \\
(0.28 \% \\
)\end{array}$ & $\begin{array}{l}17155 \\
(0.09 \%)\end{array}$ & $\begin{array}{l}4591 \\
(0.02 \\
\%)\end{array}$ \\
\hline 2009 & $\begin{array}{l}17898 \\
835\end{array}$ & $\begin{array}{l}682753 \\
9 \\
(38.15 \\
\%) \\
\end{array}$ & $\begin{array}{l}18335 \\
00 \\
(10.24 \\
\%)\end{array}$ & $\begin{array}{l}35247 \\
14 \\
(19.69 \\
\%)\end{array}$ & $\begin{array}{l}30029 \\
91 \\
(16.78 \\
\%)\end{array}$ & $\begin{array}{l}17108 \\
08 \\
(9.56 \\
\%)\end{array}$ & $\begin{array}{l}697315 \\
(3.90 \%)\end{array}$ & $\begin{array}{l}208183 \\
(1.16 \% \\
)\end{array}$ & $\begin{array}{l}41564 \\
(0.23 \% \\
)\end{array}$ & $\begin{array}{l}25302 \\
(0.14 \%)\end{array}$ & $\begin{array}{l}2691 \\
9 \\
(0.15 \\
\%)\end{array}$ \\
\hline 2010 & $\begin{array}{l}22958 \\
453\end{array}$ & $\begin{array}{l}906623 \\
0 \\
(39.49 \\
\%) \\
\end{array}$ & $\begin{array}{l}24755 \\
96 \\
(10.78 \\
\%)\end{array}$ & $\begin{array}{l}35553 \\
12 \\
(15.49 \\
\%)\end{array}$ & $\begin{array}{l}45570 \\
83 \\
(19.85 \\
\%)\end{array}$ & $\begin{array}{l}21395 \\
81 \\
(9.32 \\
\%)\end{array}$ & $\begin{array}{l}801607 \\
(3.49 \%)\end{array}$ & $\begin{array}{l}272579 \\
(1.19 \% \\
)\end{array}$ & $\begin{array}{l}61046 \\
(0.27 \% \\
)\end{array}$ & $\begin{array}{l}21239 \\
(0.09 \%)\end{array}$ & $\begin{array}{l}8180 \\
(0.04 \\
\%)\end{array}$ \\
\hline 2011 & $\begin{array}{l}34497 \\
614\end{array}$ & $\begin{array}{l}156274 \\
81 \\
(45.30 \\
\%) \\
\end{array}$ & $\begin{array}{l}34665 \\
25 \\
(10.05 \\
\%)\end{array}$ & $\begin{array}{l}37988 \\
20 \\
(11.01 \\
\%)\end{array}$ & $\begin{array}{l}64002 \\
48 \\
(18.55 \\
\%)\end{array}$ & $\begin{array}{l}27679 \\
20 \\
(8.02 \\
\%)\end{array}$ & $\begin{array}{l}100662 \\
2 \\
(2.92 \%)\end{array}$ & $\begin{array}{l}455859 \\
(1.32 \% \\
)\end{array}$ & $\begin{array}{l}89567 \\
(0.26 \% \\
)\end{array}$ & $\begin{array}{l}870606 \\
(2.52 \%)\end{array}$ & $\begin{array}{l}1396 \\
6 \\
(0.04 \\
\%)\end{array}$ \\
\hline 2012 & $\begin{array}{l}32295 \\
000\end{array}$ & $\begin{array}{l}135527 \\
11 \\
(41.97 \\
5 \%)\end{array}$ & $\begin{array}{l}36581 \\
60 \\
(11.33 \\
\%)\end{array}$ & $\begin{array}{l}37911 \\
96 \\
(11.74 \\
\%)\end{array}$ & $\begin{array}{l}60219 \\
18 \\
(18.65 \\
\%)\end{array}$ & $\begin{array}{l}34541 \\
27 \\
(10.70 \\
\%)\end{array}$ & $\begin{array}{l}111924 \\
9 \\
(3.47 \%)\end{array}$ & $\begin{array}{l}526850 \\
(1.63 \% \\
)\end{array}$ & $\begin{array}{l}110085 \\
(0.34 \% \\
)\end{array}$ & $\begin{array}{l}33396 \\
(0.10 \%)\end{array}$ & $\begin{array}{l}2730 \\
8 \\
(0.08 \\
\%)\end{array}$ \\
\hline 2013 & $\begin{array}{l}37885 \\
468\end{array}$ & $\begin{array}{l}141890 \\
22 \\
(37.45 \\
\%)\end{array}$ & $\begin{array}{l}59876 \\
14 \\
(15.80 \\
\%)\end{array}$ & $\begin{array}{l}54968 \\
21 \\
(14.51 \\
\%)\end{array}$ & $\begin{array}{l}55579 \\
39 \\
(14.67 \\
\%)\end{array}$ & $\begin{array}{l}42038 \\
13 \\
(11.10 \\
\%)\end{array}$ & $\begin{array}{l}146906 \\
8 \\
(3.88 \%)\end{array}$ & $\begin{array}{l}742867 \\
(1.96 \% \\
)\end{array}$ & $\begin{array}{l}136765 \\
(0.36 \% \\
)\end{array}$ & $\begin{array}{l}40253 \\
(0.11 \%)\end{array}$ & $\begin{array}{l}6130 \\
6 \\
(0.16 \\
\%)\end{array}$ \\
\hline 2014 & $\begin{array}{l}31294 \\
246\end{array}$ & $\begin{array}{l}967661 \\
6 \\
(30.92 \\
\%) \\
\end{array}$ & $\begin{array}{l}65265 \\
24 \\
(20.86 \\
\%) \\
\end{array}$ & $\begin{array}{l}46422 \\
33 \\
(14.83 \\
\%) \\
\end{array}$ & $\begin{array}{l}44447 \\
60 \\
(14.20 \\
\%) \\
\end{array}$ & $\begin{array}{l}34385 \\
22 \\
(10.99 \\
\%) \\
\end{array}$ & $\begin{array}{l}143690 \\
4 \\
(4.59 \%)\end{array}$ & $\begin{array}{l}868533 \\
(2.78 \% \\
)\end{array}$ & $\begin{array}{l}154065 \\
(0.49 \% \\
)\end{array}$ & $\begin{array}{l}42479 \\
(0.14 \%)\end{array}$ & $\begin{array}{l}6361 \\
0 \\
(0.20 \\
\%) \\
\end{array}$ \\
\hline 2015 & $\begin{array}{l}26428 \\
121\end{array}$ & $\begin{array}{l}780508 \\
4 \\
(29.53\end{array}$ & $\begin{array}{l}53572 \\
13 \\
(20.27\end{array}$ & $\begin{array}{l}48920 \\
61 \\
(18.51\end{array}$ & $\begin{array}{l}28688 \\
80 \\
(10.86\end{array}$ & $\begin{array}{l}31135 \\
62 \\
(11.78\end{array}$ & $\begin{array}{l}130434 \\
6 \\
(4.94 \%)\end{array}$ & $\begin{array}{l}859973 \\
(3.25 \% \\
)\end{array}$ & $\begin{array}{l}145346 \\
(0.55 \% \\
\end{array}$ & $\begin{array}{l}30392 \\
(0.11 \%)\end{array}$ & $\begin{array}{l}5126 \\
4 \\
(0.19\end{array}$ \\
\hline
\end{tabular}




\begin{tabular}{|l|l|l|l|l|l|l|l|l|l|l|l|}
\hline & & $\%)$ & $\%)$ & $\%)$ & $\%)$ & $\%)$ & & & & & $\%)$ \\
\hline $\mathbf{2 0 1 6}$ & 26381 & 735485 & 59576 & 41886 & 31315 & 29623 & 147426 & 114117 & 109283 & 37448 & 2393 \\
& 170 & 5 & 77 & 51 & 03 & 84 & 4 & 4 & $(0.41 \%$ & $(0.14 \%)$ & 1 \\
& & $(27.88$ & $(22,58$ & $(15.88$ & $(11.87$ & $(11.23$ & $(5.59 \%)$ & $(4.33 \%$ & ) & & $(0.09$ \\
& & $\%)$ & $\%)$ & $\%)$ & $\%)$ & $\%)$ & & ) & & & $\%)$ \\
\hline CA & $\mathbf{1 6 . 3 9}$ & $\mathbf{1 5 . 4}$ & $\mathbf{2 6 . 7 5}$ & $\mathbf{1 5 . 7 9}$ & $\mathbf{1 4 . 8 7}$ & $\mathbf{1 3 . 5 5}$ & $\mathbf{1 2 . 4}$ & $\mathbf{2 2 . 6 4}$ & $\mathbf{1 9 . 2}$ & $\mathbf{2 3 . 1 5}$ & $\mathbf{2 9 . 8 2}$ \\
GR & & & & & & & & & & & \\
\hline
\end{tabular}

Source-http://www.trademap.org/stDataSources

The commitment and efforts by India to intensify its economic relations with ASEAN are evident from a Framework Agreement on Comprehensive Economic Co-operation between ASEAN and India in October 2003, being signed by the Indian Prime Minister during the Second ASEAN-India Summit in Bali. Table-II focused on India's exports with 10 Individual nations of South East Asia. It needs to be emphasized that among all ASEAN member countries five nations are the top export destination. Those states are Singapore, Viet Nam, Malaysia, Indonesia, and Thailand. India's export to ASEAN touched the highest value ever during 2013 i.e. 37885468 thousand USD. Singapore stood as first export destination of India in comparison to other SEA nations. The second was Indonesia during 2001 2012. From 2013 onward Vietnam secured the second position. India's export is very low to Brunei and Laos in the context of relative percentage but Compound Annual Growth rate is high at $23.15 \%$ \& $29.82 \%$ respectively. Cooperation between ASEAN and India is expected to encompass a strategic and political partnership, thus going well beyond a traditional Free Trade Agreement (FTA). Trend and growth of India's exports to various ASEAN nations during the period from 2001-16 shows that Singapore is the nation with whom India has the highest percentage of exports of total exports to ASEAN countries, followed by Malaysia, Thailand and Indonesia respectively, countries of ASEAN such as Vietnam, Brunei Myanmar and Cambodia though had a lesser share of total exports from India to ASEAN, have experienced a higher growth rate in terms of value of exports compared to other member countries during the study period. The compound growth rate of total exports to Vietnam, Brunei, Myanmar and Cambodia are $26.75 \%, 23.15 \%, 22.64 \%$ and $19.2 \%$ percent respectively which are more than the compound growth of total exports to ASEAN countries. It is worth probing whether this scenario is the result of the emergence of CLMV (Cambodia, Lao PDR, Myanmar, and Vietnam). It is observed that the growth of India's Exports to Cambodia, Laos, Brunei and Myanmar, Vietnam also confirm that ASEAN on the whole has great trade potential and IndoASEAN trade has a lot of scope for future. The growth rate of Vietnam also proves this New Delhi's views on Vietnam as "a strong pillar" of its AEP, whereas Vietnam supports the policy, but wants India to play a more active role in the region's affairs.(Vinh,2016)

\section{India's Export to various Economic organizations: A comparative study:-}

Cooperation is nothing but the willingness of individuals, societies or nations to help each other. Cooperation is voluntary in nature. It begins initially at community level and extends to national, regional and international level. Regional economic cooperation means collaborating among a group of countries on economic matters for mutual benefits and wellbeing. (Chase, 2006) India has a growing international influence and a prominent voice in global affairs. India was one of the founding members of several international organizations - the United Nations, the Asian Development Bank, New Development BRICS Bank, and G-20 - and the founder of the Non-Aligned Movement. India has signed strategic partnership agreements with more than two dozen states. By the UNO different regional trade blocs are made as European Union, ASEAN, SAARC, APEC and many in different regions of the world. India is participating in different trade blocs for economic cooperation. India was one of the first countries to develop relations with predecessors of the European Union. In 1963, India begins a diplomatic dialogue with the European Economic Community (EEC).(IndiaToday,2012)In 2004, India and the European Union started a "Strategic Dialogue" and in 2005 a Joint Action Plan was decided upon and updated in 2008. The joint statement of India-EU was published in 2009 and 2012 following the India-European Union Summits. India has sustained and strengthens its meeting with the EU, a strategic partner, as well as individual countries in Europe in diverse fields such as defence and security, nuclear and space, trade and investment, energy, climate change, science and technology, culture and education. India views cooperation with ASEAN, and the countries in the Asia-Pacific, as an important dimension of its diplomacy in the 21st century as reflected in India's "Look East Policy" which is present "Act East policy". India considerably extended its network of economic and technical cooperation in 2009. India is ready to play a significant role in recently established forums such as IRC (India-Russia-China), BRIC (Brazil-Russia-India-China) and IBSA (India-Brazil-South Africa). India continues to engage Mekong-Ganga Cooperation, G-15, and the G-8. Regionally, India is a part of SAARC and BIMSTEC. SAARC is a group of developing countries. The following table gives the value of India's export to five international organizations and to 
the world as a whole. Five economic organizations have been taken for comparison i.e. ASEAN, BRICS, SAARC, EU and APEC.

Table-III:-India' exports to various organizations during 2001-16

\begin{tabular}{|c|c|c|c|c|c|c|}
\hline Total export to & WORLD & ASEAN & BRICS & SAARC & EU & APEC \\
\hline \multicolumn{7}{|l|}{ YEAR } \\
\hline 2001 & 43878489 & $\begin{array}{l}3315112 \\
(9.0 \%)\end{array}$ & $\begin{array}{l}2319324 \\
(5.3 \%)\end{array}$ & $\begin{array}{l}2092222 \\
(4.8 \%)\end{array}$ & $\begin{array}{l}10344572 \\
(23.6 \%)\end{array}$ & $\begin{array}{l}19599242 \\
(44.7 \%)\end{array}$ \\
\hline 2002 & 50097958 & $\begin{array}{l}4503303 \\
(7.6 \%)\end{array}$ & $\begin{array}{l}3101456 \\
(6.2 \%)\end{array}$ & $\begin{array}{l}2415180 \\
(4.8 \%)\end{array}$ & $\begin{array}{l}11343897 \\
(22.6 \%)\end{array}$ & $\begin{array}{l}23960772 \\
(47.8 \%)\end{array}$ \\
\hline 2003 & 59360659 & $\begin{array}{l}5071800 \\
(8.5 \%)\end{array}$ & $\begin{array}{l}4119135 \\
(6.9 \%)\end{array}$ & $\begin{array}{l}3875186 \\
(6.5 \%)\end{array}$ & $\begin{array}{l}13521440 \\
(22.8 \%)\end{array}$ & $\begin{array}{l}27488118 \\
(46.3 \%)\end{array}$ \\
\hline 2004 & 75904200 & $\begin{array}{l}7552218 \\
(9.9 \%)\end{array}$ & $\begin{array}{l}6162395 \\
(8.1 \%)\end{array}$ & $\begin{array}{l}4579673 \\
(6.0 \%)\end{array}$ & $\begin{array}{l}16755442 \\
(22.1 \%)\end{array}$ & $\begin{array}{l}34104751 \\
(44.9 \%)\end{array}$ \\
\hline 2005 & 100352637 & $\begin{array}{l}10285769 \\
(10.2 \%)\end{array}$ & $\begin{array}{l}10263390 \\
(10.2 \%)\end{array}$ & $\begin{array}{l}5399782 \\
(5.4 \%) \\
\end{array}$ & $\begin{array}{l}22645006 \\
(22.6 \%)\end{array}$ & $\begin{array}{l}46199090 \\
(46.0 \%)\end{array}$ \\
\hline 2006 & 121200606 & $\begin{array}{l}12369341 \\
(10.2 \%)\end{array}$ & $\begin{array}{l}12267445 \\
(10.1 \%)\end{array}$ & $\begin{array}{l}6232732 \\
(5.1 \%)\end{array}$ & $\begin{array}{l}25980980 \\
(21.4 \%)\end{array}$ & $\begin{array}{l}53359257 \\
(44.0 \%)\end{array}$ \\
\hline 2007 & 145898053 & $\begin{array}{l}13824081 \\
(9.5 \%)\end{array}$ & $\begin{array}{l}14445464 \\
(9.9 \%)\end{array}$ & $\begin{array}{l}7848397 \\
(5.4 \%)\end{array}$ & $\begin{array}{l}31687146 \\
(21.7 \%)\end{array}$ & $\begin{array}{l}60598113 \\
(41.5 \%)\end{array}$ \\
\hline 2008 & 181860898 & $\begin{array}{l}19433467 \\
(10.7 \%)\end{array}$ & $\begin{array}{l}16915669 \\
(9.3 \%)\end{array}$ & $\begin{array}{l}10130441 \\
(5.6 \%)\end{array}$ & $\begin{array}{l}39292194 \\
(21.6 \%)\end{array}$ & $\begin{array}{l}72153090 \\
(39.7 \%)\end{array}$ \\
\hline 2009 & 176765036 & $\begin{array}{l}17898835 \\
(10.1 \%)\end{array}$ & $\begin{array}{l}15075993 \\
(8.5 \%)\end{array}$ & $\begin{array}{l}7373574 \\
(4.2 \%)\end{array}$ & $\begin{array}{l}36388891 \\
(20.6 \%)\end{array}$ & $\begin{array}{l}67381336 \\
(38.1 \%)\end{array}$ \\
\hline 2010 & 220408496 & $\begin{array}{l}22958453 \\
(10.4 \%)\end{array}$ & $\begin{array}{l}26152830 \\
(11.9 \%)\end{array}$ & $\begin{array}{l}11114204 \\
(5.0 \%)\end{array}$ & $\begin{array}{l}41595235 \\
(18.9 \%)\end{array}$ & $\begin{array}{l}90053663 \\
(40.9 \%)\end{array}$ \\
\hline 2011 & 301483250 & $\begin{array}{l}34497614 \\
(11.4 \%)\end{array}$ & $\begin{array}{l}28322581 \\
(9.4 \%)\end{array}$ & $\begin{array}{l}12937536 \\
(4.3 \%)\end{array}$ & $\begin{array}{l}54732556 \\
(18.2 \%)\end{array}$ & $\begin{array}{l}118158273 \\
(39.2 \%)\end{array}$ \\
\hline 2012 & 289564769 & $\begin{array}{l}32295000 \\
(11.2 \%)\end{array}$ & $\begin{array}{l}28010095 \\
(9.7 \%)\end{array}$ & $\begin{array}{l}13738380 \\
(4.7 \%)\end{array}$ & $\begin{array}{l}48642542 \\
(16.8 \%)\end{array}$ & $\begin{array}{l}118800582 \\
(41.0 \%)\end{array}$ \\
\hline 2013 & 336611389 & $\begin{array}{l}37885468 \\
(11.3 \%)\end{array}$ & $\begin{array}{l}30690091 \\
(9.1 \%)\end{array}$ & $\begin{array}{l}16899974 \\
(5.0 \%)\end{array}$ & $\begin{array}{l}56284264 \\
(16.7 \%)\end{array}$ & $\begin{array}{l}134454001 \\
(39.9 \%)\end{array}$ \\
\hline 2014 & 317544642 & $\begin{array}{l}31294246 \\
(9.9 \%)\end{array}$ & $\begin{array}{l}28514642 \\
(9.0 \%)\end{array}$ & $\begin{array}{l}19836415 \\
(6.2 \%)\end{array}$ & $\begin{array}{l}51569528 \\
(16.2 \%)\end{array}$ & $\begin{array}{l}124019363 \\
(39.1 \%)\end{array}$ \\
\hline 2015 & 264381004 & $\begin{array}{l}26428121 \\
(10.0 \%)\end{array}$ & $\begin{array}{l}18101985 \\
(6.8 \%)\end{array}$ & $\begin{array}{l}17257457 \\
(6.5 \%)\end{array}$ & $\begin{array}{l}44705937 \\
(16.9 \%)\end{array}$ & $\begin{array}{l}108502837 \\
(41.0 \%)\end{array}$ \\
\hline 2016 & 260326912 & $\begin{array}{l}26381170 \\
(10.1 \%)\end{array}$ & $\begin{array}{l}16273317 \\
(6.3 \%)\end{array}$ & $\begin{array}{l}16933209 \\
(6.5 \%)\end{array}$ & $\begin{array}{l}45747582 \\
(17.6 \%)\end{array}$ & $\begin{array}{l}110137100 \\
(42.3 \%)\end{array}$ \\
\hline CAGR & 14.71 & 16.39 & 15.97 & 15.42 & 11.75 & 13.5 \\
\hline
\end{tabular}

\section{Source-http://www.trademap.org/stDataSources}

APEC is the top export destination of India and ASEAN occupies the third position in this table. The percentage of India's export to the ASEAN in relations to total export has increased from $9.0 \%$ to $11.4 \%$ in 2011 and it has declined in recent years to $10.1 \%$ in 2016. The percentage of India's export to the BRICS in relation to total export has increased from 5.3\% in 2001 to $11.9 \%$ in 2010 and it has declined in recent years to $6.3 \%$. The percentage of India's export to the SAARC in comparison to total export has increased from $4.8 \%$ in 2001 to $6.5 \%$ in recent years in 2016 in spite of the unstable export rate. But in the context of EU and APEC the export value was 23.6\%, 44.7\% in 2001 respectively. It has come down $17.6 \%, 42.3 \%$ respectively in recent years in 2016. The percentage in the bracket shows the relative share of exports to each organization as a proportion of total exports to the world to reflect the significance of each organization as a trade partner of India. Compound growth rates are calculated to show the growth of exports to different regional organizations during the study period. It is to be noted that since only five organizations have been selected for study in terms of exports from India the total percentage does not necessarily come to cent percent. This table also reflects Compound Annual Growth Rate (CAGR) of total export of India to the selected organizations. The CAGR of India's export to ASEAN is $16.39 \%$ which is maximum in comparison with other groups as well as with that to the world. In terms of value of exports APEC \& EU are found 
more significant export destinations of India whereas ASEAN occupies the third position followed by BRICS and SAARC. But exports to ASEAN has experienced highest growth rate during the study period. From the table-III it can be observed that the growth rate of ASEAN in comparison to other economic organizations has immense export scope for future.

\section{Russia's relations with ASEAN:-}

Previously, Russia has not had a very strong relationship with Southeast Asian nations, with the exception of strong Cold War ties with the then North Vietnam. For a long time, Russia's relations with ASEAN had been limited to the political sphere. Diplomatic influence without the underlying economic basis was a correct description of Russia's policy toward ASEAN in the 1990s. Despite the fact that political partnership had been on the rise during that decade, little progress was made in the field of economic cooperation. Ultimately, traditionally weak economic links between Russia and Southeast Asia also hindered Russia's search for influence. There is no longer any reason for the intense political suspicion and fear that characterized the relationship between Moscow and Southeast Asia during the Cold War when Southeast Asia was one of the most violent and bitterly contested zones of international rivalry. Today neither Southeast Asian governments nor Russia have vital security issues at stake in their bilateral relation. Russia and ASEAN have held multiple dialogues on the content of the roadmap. After the Joint Declaration and Agreements were signed in December 2005, it took nearly five years to begin discussion on an implementation roadmap. These discussions finally began in July 2010, during the senior economic officials' consultations in Brunei, and were followed by a decision in late October 2010 to begin drafting the roadmap. It then took seven months for Russia to get final approval by all the relevant Federal agencies. In fact four senior officials' consultations were held in 2011-2012. The dialogues have disseminated numerous instructions on protocols. However, it took another year and half until the roadmap was approved at the ministerial level meeting in October 2012. Reaching an FTA with Vietnam will move Russia closer to a Russia-ASEAN Free Trade Agreement, which has been in discussion for the last several years. In fact most business ties between Russia and Southeast Asian countries have been concluded on a bilateral basis. However, creating a Russia-ASEAN FTA will transform the relationship into a larger, regional one. (Torres 2013) The real interaction between Russia and SEA nations remains open. The $20^{\text {th }}$ anniversary of the Russia-ASEAN Dialogue Partnership in 2016 is a good occasion to investigate new sources of development for Russian-ASEAN relations.(Tsvetov,2016) The following table reflects the Russia's exports to ASEAN and imports from ASEAN in absolute terms i.e. in dollar as well as in percent showing the proportion of Russia's export and import relation with ASEAN in the context of total exports and imports status with the world.

Table-IV:-Russia's Export, Import \& Trade Balance with ASEAN

\begin{tabular}{|c|c|c|c|c|c|c|c|}
\hline \multicolumn{4}{|c|}{ Russia's Export To ASEAN } & \multicolumn{4}{|c|}{ Russia's Import From ASEAN } \\
\hline Year & World & ASEAN & Percentage & World & ASEAN & Percentage & $\begin{array}{l}\text { TRADE } \\
\text { BALANCE }\end{array}$ \\
\hline 2001 & 99868397 & 1197286 & $1.20 \%$ & 41865362 & 576552 & $1.38 \%$ & 620734 \\
\hline 2002 & 106691998 & 1510597 & $1.42 \%$ & 46176985 & 833777 & $1.81 \%$ & 676820 \\
\hline 2003 & 133655685 & 1503703 & $1.13 \%$ & 57345988 & 992896 & $1.73 \%$ & 510807 \\
\hline 2004 & 181600379 & 1777346 & $0.98 \%$ & 75569015 & 1315950 & $1.74 \%$ & 461396 \\
\hline 2005 & 241451657 & 2159188 & $0.89 \%$ & 98707256 & 2046720 & $2.07 \%$ & 112468 \\
\hline 2006 & 301550666 & 1959779 & $0.65 \%$ & 137811060 & 2759584 & $2.00 \%$ & -799805 \\
\hline 2007 & 352266399 & 2563296 & $0.73 \%$ & 199725955 & 4251889 & $2.13 \%$ & -1688593 \\
\hline 2008 & 467993955 & 4371332 & $0.93 \%$ & 267051244 & 5784301 & $2.17 \%$ & -1412969 \\
\hline 2009 & 301796059 & 3607525 & $1.20 \%$ & 170826590 & 4297428 & $2.52 \%$ & -689903 \\
\hline 2010 & 397067521 & 6513607 & $1.64 \%$ & 228911658 & 5553979 & $2.43 \%$ & 959628 \\
\hline 2011 & 516992618 & 7857342 & $1.52 \%$ & 306091490 & 7584705 & $2.48 \%$ & 272637 \\
\hline 2012 & 524766421 & 7305484 & $1.39 \%$ & 316192918 & 8297211 & $2.62 \%$ & -991727 \\
\hline 2013 & 527265919 & 8490895 & $1.61 \%$ & 314945095 & 8986358 & $2.85 \%$ & -495463 \\
\hline 2014 & 497833529 & 11796276 & $2.37 \%$ & 286648777 & 8781659 & $3.06 \%$ & 3014617 \\
\hline 2015 & 343907652 & 5352480 & $1.56 \%$ & 182781965 & 7304524 & $4.00 \%$ & -1952044 \\
\hline 2016 & 285491052 & 5566876 & $1.95 \%$ & 182261656 & 8001965 & $4.39 \%$ & -2435089 \\
\hline CAGR & $9.7 \%$ & $14.87 \%$ & & $12.91 \%$ & $20.05 \%$ & & \\
\hline
\end{tabular}

Source-http://www.trademap.org/stDataSources 
In the 21 st century Russia-ASEAN trade appears to have grown at an impressive rate with exports growing at a rate of $14.87 \%$ and imports growing at $20.05 \%$. Russia's trade relation in terms of exports and imports as a proportion of its trade with the world has not been very significant, varying between $0.65 \%$ to $1.95 \%$. In most of the period imports size has been more than exports. From the study period of sixteen years, there has been a negative trade balance in eight years. From 2001 to 2005, there was a positive trade balance, but since 2005 there has been negative trade balance except in 2010, 2011, 2012. In the years 2015 and 2016, the percentage of imports from ASEAN in proportion to total imports from the world has gone above $4 \%$, causing a larger trade deficit. Russia's trade relations with the ASEAN nations have not been very affirmative. However in spite of a history of Cold War suspicion, at present the trade relations between Russia and some member countries of ASEAN have gained momentum. It is found that after 2009 the export of Russia has not increased significantly in comparison with import from ASEAN. Here one finds that Russia's import from ASEAN has grown impressively which was $1.38 \%$ in 2001 and which touched $4.39 \%$ in 2016.The above figure proves positive trade relation between Russia and ASEAN because Russia's import from the ASEAN is higher than export to it. The above figures also focus on CAGR of Russia's export to and import from world in comparison with ASEAN. Here the important finding is that the CAGR of Russia's import from ASEAN is higher than export to it. Russia's growth rate in connection with import from ASEAN is $20.05 \%$ and export to ASEAN is $14.87 \%$.

A Comparison of Two Tables (No.I \& No.IV):-

(Table-I showing India's export to and Import from ASEAN and Table-IV Showing Russia's export to and Import from ASEAN):-

A comparison of the two tables shows that Russia in the study period is making more imports from ASEAN than exporting to it. But in comparison with other organizations it is exporting more to ASEAN. The CAGR OF Russia's export to ASEAN is $14.8 \%$ maximum compared to other organizations and to the world as well. The CAGR of India's export is displayed in the table is $16.39 \%$, which is maximum in comparison with other organizations as well as the world. Russia is exporting arms and selling petroleum products to individual SEA nations.

\section{Russia \& Member states of ASEAN:-}

The Association of South East Asian Nations (ASEAN) is the successful organizations in the region. The strategic importance of ASEAN is also determined by its role as the main driving force of integration in the Asia-Pacific region (APR). In the geographical and political point of view Russia is nearby Asia-Pacific region APR, but its relations with the region is not so good, in comparison to other countries. Though in the past, Russia has not had a strong association with Southeast Asian countries but Vietnam, Cambodia, and Laos had been cold-war allies of the Soviet Union prior to their inclusion in ASEAN. After the dissolution of the Soviet Union under President Boris Yeltsin's leadership, Russia lost its position even in countries where it previously had influence. In the beginning of the 1990s the role of Southeast Asia in Russian foreign policy was uncertain. In 1996, Russia became a full dialogue partner of ASEAN, and over the next few years Russia-ASEAN cooperation commences to be twisted. The basic elements constituting the legal framework of Russian-ASEAN cooperation are the Joint Declaration on Progressive and Comprehensive Partnership, the Agreement on Economic and Development Cooperation, and the Comprehensive Program of Action to boost up Cooperation for 2005-2015. (Mirkasymov, 2007) Russia's failure in actively participating in banking and investment cooperation with ASEAN states is clearly noticeable. The number of joint ventures is relatively few. Till now the Vietnam-Russia Joint Venture Bank, founded in 2009, is the sole institution of cooperation. Adequate attention is not given by the Russian state structures to the needs of private enterprise. (Martynova,2014) On the occasion of third ASEAN-Russia summit, on 2016 Russian President Vladimir Putin held bilateral meetings with the leader of every member-state of the Association of Southeast Asian Nations (ASEAN) over two days. Russia-Malaysia Business Council was launched, with the goal of promoting Malaysia as a regional hub for Russian investment in the ASEAN countries. Federation Council Speaker Valentina Matviyenko also held talks with Singapore's prime minister in advance of his visit to Russia in May, in particular to begin drafting the relevant agreements to expand the bilateral relationship. Singapore's defense minister also traveled to Moscow in April for a security conference and bilateral meetings with his Russian counterpart. (Gvosdev, 2016)

Table-V:-Trend and growth of Russia's exports to various ASEAN nations during 2001-16

\begin{tabular}{|c|c|c|c|c|c|c|c|c|c|c|}
\hline & $\begin{array}{c}\text { ASEA } \\
\text { N }\end{array}$ & $\begin{array}{c}\text { Singa } \\
\text { pore }\end{array}$ & $\begin{array}{c}\text { Viet } \\
\text { Nam }\end{array}$ & $\begin{array}{c}\text { Mala } \\
\text { ysia }\end{array}$ & $\begin{array}{c}\text { Thail } \\
\text { and }\end{array}$ & $\begin{array}{c}\text { Indon } \\
\text { esia }\end{array}$ & $\begin{array}{c}\text { Philipp } \\
\text { ines }\end{array}$ & $\begin{array}{c}\text { Myan } \\
\text { mar }\end{array}$ & $\begin{array}{c}\text { Cambodia } \\
\text { Brunei } \\
\text { Darussal } \\
\text { am }\end{array}$ & $\begin{array}{c}\text { Lao } \\
\text { and }\end{array}$ \\
\hline
\end{tabular}




\begin{tabular}{|c|c|c|c|c|c|c|c|c|c|c|c|}
\hline $\begin{array}{l}\text { YE } \\
\mathbf{A R}\end{array}$ & & & & & & & & & & & \\
\hline $\begin{array}{c}200 \\
1\end{array}$ & $\begin{array}{r}11972 \\
86\end{array}$ & $\begin{array}{r}57452 \\
0 \\
(47.99 \\
\%)\end{array}$ & $\begin{array}{r}16284 \\
7 \\
(13.60 \\
\%)\end{array}$ & $\begin{array}{r}26928 \\
3 \\
(22.49 \\
\%)\end{array}$ & $\begin{array}{r}71378 \\
(5.96 \\
\%)\end{array}$ & $\begin{array}{r}31135 \\
(2.60 \\
\%)\end{array}$ & $\begin{array}{r}46223 \\
(3.86 \% \\
)\end{array}$ & $\begin{array}{r}33398 \\
(2.79 \\
\%)\end{array}$ & $\begin{array}{r}4745 \\
(0.40 \%)\end{array}$ & $\begin{array}{r}0 \\
(0.00 \%)\end{array}$ & $\begin{array}{r}3757 \\
(0.31 \\
\%)\end{array}$ \\
\hline $\begin{array}{c}200 \\
2\end{array}$ & $\begin{array}{r}15105 \\
97\end{array}$ & $\begin{array}{r}52183 \\
8 \\
(34.55 \\
\%) \\
\end{array}$ & $\begin{array}{r}32141 \\
1 \\
(21.28 \\
\%) \\
\end{array}$ & $\begin{array}{r}34763 \\
9 \\
(23.01 \\
\%) \\
\end{array}$ & $\begin{array}{r}96021 \\
(6.36 \\
\%)\end{array}$ & $\begin{array}{r}30677 \\
(2.03 \\
\%)\end{array}$ & $\begin{array}{r}97804 \\
(6.47 \% \\
)\end{array}$ & $\begin{array}{r}87905 \\
(5.82 \\
\%)\end{array}$ & $\begin{array}{r}3290 \\
(0.22 \%)\end{array}$ & $\begin{array}{r}0 \\
(0.00 \%)\end{array}$ & $\begin{array}{r}4012 \\
(0.27 \\
\%)\end{array}$ \\
\hline $\begin{array}{c}200 \\
3\end{array}$ & $\begin{array}{r}15037 \\
03\end{array}$ & $\begin{array}{r}15818 \\
1 \\
(10.52 \\
\%)\end{array}$ & $\begin{array}{r}35719 \\
8 \\
(23.75 \\
\%) \\
\end{array}$ & $\begin{array}{r}42508 \\
0 \\
(28.27 \\
\%)\end{array}$ & $\begin{array}{r}13041 \\
3 \\
(8.67 \\
\%)\end{array}$ & $\begin{array}{r}23561 \\
8 \\
(15.67 \\
\%)\end{array}$ & $\begin{array}{r}183350 \\
(12.19 \\
\%)\end{array}$ & $\begin{array}{r}10656 \\
(0.71 \\
\%)\end{array}$ & $\begin{array}{r}984 \\
(0.07 \%)\end{array}$ & $\begin{array}{r}0 \\
(0.00 \%)\end{array}$ & $\begin{array}{r}2223 \\
(0.15 \\
\%)\end{array}$ \\
\hline $\begin{array}{c}200 \\
4\end{array}$ & $\begin{array}{r}17773 \\
46\end{array}$ & $\begin{array}{r}18975 \\
3 \\
(10.68 \\
\%) \\
\end{array}$ & $\begin{array}{r}70748 \\
6 \\
(39.81 \\
\%) \\
\end{array}$ & $\begin{array}{r}11428 \\
0 \\
(6.43 \\
\%) \\
\end{array}$ & $\begin{array}{r}37249 \\
1 \\
(20.96 \\
\%) \\
\end{array}$ & $\begin{array}{r}14540 \\
4 \\
(8.18 \\
\%) \\
\end{array}$ & $\begin{array}{r}216723 \\
(12.19 \\
\%)\end{array}$ & $\begin{array}{r}23195 \\
(1.31 \\
\%)\end{array}$ & $\begin{array}{r}1535 \\
(0.09 \%)\end{array}$ & $\begin{array}{r}0 \\
(0.00 \%)\end{array}$ & $\begin{array}{r}6479 \\
(0.36 \\
\%)\end{array}$ \\
\hline $\begin{array}{c}200 \\
5\end{array}$ & $\begin{array}{r}21591 \\
88\end{array}$ & $\begin{array}{r}30916 \\
4 \\
(14.32 \\
\%)\end{array}$ & $\begin{array}{r}73880 \\
0 \\
(34.22 \\
\%)\end{array}$ & $\begin{array}{r}15009 \\
7 \\
(6.95 \\
\%)\end{array}$ & $\begin{array}{r}54667 \\
4 \\
(25.32 \\
\%)\end{array}$ & $\begin{array}{r}20245 \\
0 \\
(9.38 \\
\%) \\
\end{array}$ & $\begin{array}{r}197991 \\
(9.17 \% \\
)\end{array}$ & $\begin{array}{r}692 \\
(0.03 \\
\%)\end{array}$ & $\begin{array}{r}2426 \\
(0.11 \%)\end{array}$ & $\begin{array}{r}1 \\
(0.00 \%)\end{array}$ & $\begin{array}{r}1089 \\
3 \\
(0.50 \\
\%) \\
\end{array}$ \\
\hline $\begin{array}{c}200 \\
6\end{array}$ & $\begin{array}{r}19597 \\
79\end{array}$ & $\begin{array}{r}79043 \\
1 \\
(40.33 \\
\%) \\
\end{array}$ & $\begin{array}{r}30363 \\
0 \\
(15.49 \\
\%) \\
\end{array}$ & $\begin{array}{r}23926 \\
4 \\
(12.21 \\
\%) \\
\end{array}$ & $\begin{array}{r}34710 \\
9 \\
(17.71 \\
\%) \\
\end{array}$ & $\begin{array}{r}18690 \\
7 \\
(9.54 \\
\%) \\
\end{array}$ & $\begin{array}{r}79252 \\
(4.04 \% \\
)\end{array}$ & $\begin{array}{r}6549 \\
(0.33 \\
\%)\end{array}$ & $\begin{array}{r}3035 \\
(0.15 \%)\end{array}$ & $\begin{array}{r}17 \\
(0.00 \%)\end{array}$ & $\begin{array}{r}3585 \\
(0.18 \\
\%)\end{array}$ \\
\hline $\begin{array}{c}200 \\
7\end{array}$ & $\begin{array}{r}25632 \\
96\end{array}$ & $\begin{array}{r}10877 \\
90 \\
(42.44 \\
\%) \\
\end{array}$ & $\begin{array}{r}48477 \\
4 \\
(18.91 \\
\%) \\
\end{array}$ & $\begin{array}{r}26830 \\
9 \\
(10.47 \\
\%) \\
\end{array}$ & $\begin{array}{r}32711 \\
0 \\
(12.76 \\
\%) \\
\end{array}$ & $\begin{array}{r}25069 \\
3 \\
(9.78 \\
\%) \\
\end{array}$ & $\begin{array}{r}117277 \\
(4.58 \% \\
)\end{array}$ & $\begin{array}{r}14494 \\
(0.57 \\
\%)\end{array}$ & $\begin{array}{r}11160 \\
(0.44 \%)\end{array}$ & $\begin{array}{r}1 \\
(0.00 \%)\end{array}$ & $\begin{array}{r}1688 \\
(0.07 \\
\%)\end{array}$ \\
\hline $\begin{array}{c}200 \\
8\end{array}$ & $\begin{array}{r}43713 \\
32\end{array}$ & $\begin{array}{r}11803 \\
15 \\
(27.00 \\
\%) \\
\end{array}$ & $\begin{array}{r}58091 \\
4 \\
(13.29 \\
\%) \\
\end{array}$ & $\begin{array}{r}47105 \\
7 \\
(10.78 \\
\%) \\
\end{array}$ & $\begin{array}{r}12321 \\
92 \\
(28.19 \\
\%) \\
\end{array}$ & $\begin{array}{r}61620 \\
6 \\
(14.10 \\
\%) \\
\end{array}$ & $\begin{array}{r}243215 \\
(5.56 \% \\
)\end{array}$ & $\begin{array}{r}32309 \\
(0.74 \\
\%)\end{array}$ & $\begin{array}{r}8629 \\
(0.20 \%)\end{array}$ & $\begin{array}{r}802 \\
(0.02 \%)\end{array}$ & $\begin{array}{r}5693 \\
(0.13 \\
\%)\end{array}$ \\
\hline $\begin{array}{c}200 \\
9\end{array}$ & $\begin{array}{r}36075 \\
25\end{array}$ & $\begin{array}{r}13270 \\
00 \\
(36.78 \\
\%) \\
\end{array}$ & $\begin{array}{r}86900 \\
0 \\
(24.09 \\
\%) \\
\end{array}$ & $\begin{array}{r}21726 \\
6 \\
(6.02 \\
\%) \\
\end{array}$ & $\begin{array}{r}43924 \\
5 \\
(12.18 \\
\%) \\
\end{array}$ & $\begin{array}{r}28320 \\
5 \\
(7.85 \\
\%) \\
\end{array}$ & $\begin{array}{r}406871 \\
(11.28 \\
\%)\end{array}$ & $\begin{array}{r}45424 \\
(1.26 \\
\%)\end{array}$ & $\begin{array}{r}9278 \\
(0.26 \%)\end{array}$ & $\begin{array}{r}162 \\
(0.00 \%)\end{array}$ & $\begin{array}{r}1007 \\
4 \\
(0.28 \\
\%) \\
\end{array}$ \\
\hline $\begin{array}{c}201 \\
0\end{array}$ & $\begin{array}{r}65136 \\
07\end{array}$ & $\begin{array}{r}20081 \\
69 \\
(30.83 \\
\%) \\
\end{array}$ & $\begin{array}{r}11208 \\
28 \\
(17.21 \\
\%) \\
\end{array}$ & $\begin{array}{r}34477 \\
5 \\
(5.29 \\
\%) \\
\end{array}$ & $\begin{array}{r}15360 \\
94 \\
(23.58 \\
\%) \\
\end{array}$ & $\begin{array}{r}66501 \\
0 \\
(10.21 \\
\%) \\
\end{array}$ & $\begin{array}{r}763343 \\
(11.72 \\
\%)\end{array}$ & $\begin{array}{r}62662 \\
(0.96 \\
\%)\end{array}$ & $\begin{array}{r}5733 \\
(0.09 \%)\end{array}$ & $\begin{array}{r}25 \\
(0.00 \%)\end{array}$ & $\begin{array}{r}6968 \\
(0.11 \\
\%)\end{array}$ \\
\hline $\begin{array}{c}201 \\
1\end{array}$ & $\begin{array}{r}78573 \\
42\end{array}$ & $\begin{array}{r}22501 \\
33 \\
(28.64 \\
\%) \\
\end{array}$ & $\begin{array}{r}10101 \\
46 \\
(12.86 \\
\%) \\
\end{array}$ & $\begin{array}{r}41730 \\
3 \\
(5.31 \\
\%) \\
\end{array}$ & $\begin{array}{r}20977 \\
82 \\
(26.70 \\
\%) \\
\end{array}$ & $\begin{array}{r}57972 \\
4 \\
(7.38 \\
\%) \\
\end{array}$ & $\begin{array}{r}121766 \\
0 \\
(15.50 \\
\%) \\
\end{array}$ & $\begin{array}{r}27019 \\
6 \\
(3.44 \\
\%) \\
\end{array}$ & $\begin{array}{r}3813 \\
(0.05 \%)\end{array}$ & $\begin{array}{r}432 \\
(0.01 \%)\end{array}$ & $\begin{array}{r}1015 \\
3 \\
(0.13 \\
\%) \\
\end{array}$ \\
\hline $\begin{array}{c}201 \\
2\end{array}$ & $\begin{array}{r}73054 \\
84\end{array}$ & $\begin{array}{r}15893 \\
33 \\
(21.76 \\
\%) \\
\end{array}$ & $\begin{array}{r}13885 \\
92 \\
(19.01 \\
\%) \\
\end{array}$ & $\begin{array}{r}27592 \\
2 \\
(3.78 \\
\%) \\
\end{array}$ & $\begin{array}{r}14114 \\
26 \\
(19.32 \\
\%) \\
\end{array}$ & $\begin{array}{r}13100 \\
80 \\
(17.93 \\
\%) \\
\end{array}$ & $\begin{array}{r}118329 \\
6 \\
(16.20 \\
\%) \\
\end{array}$ & $\begin{array}{r}13108 \\
9 \\
(1.79 \\
\%) \\
\end{array}$ & $\begin{array}{r}5881 \\
(0.08 \%)\end{array}$ & $\begin{array}{r}14 \\
(0.00 \%)\end{array}$ & $\begin{array}{r}9851 \\
(0.13 \\
\%)\end{array}$ \\
\hline $\begin{array}{c}201 \\
3\end{array}$ & $\begin{array}{r}84908 \\
95\end{array}$ & $\begin{array}{r}18855 \\
89 \\
(22.21 \\
\%) \\
\end{array}$ & $\begin{array}{r}13734 \\
61 \\
(16.18 \\
\%) \\
\end{array}$ & $\begin{array}{r}12803 \\
76 \\
(15.08 \\
\%) \\
\end{array}$ & $\begin{array}{r}12729 \\
43 \\
(14.99 \\
\%) \\
\end{array}$ & $\begin{array}{r}12335 \\
54 \\
(14.53 \\
\%) \\
\end{array}$ & $\begin{array}{r}132386 \\
6 \\
(15.59 \\
\%) \\
\end{array}$ & $\begin{array}{r}78692 \\
(0.93 \\
\%)\end{array}$ & $\begin{array}{r}5096 \\
(0.06 \%)\end{array}$ & $\begin{array}{r}2 \\
(0.00 \%)\end{array}$ & $\begin{array}{r}3731 \\
6 \\
(0.44 \\
\%) \\
\end{array}$ \\
\hline 201 & 11796 & 55518 & 64453 & 18195 & 17513 & 91832 & 105947 & 39027 & 3765 & 27 & 8325 \\
\hline
\end{tabular}




\begin{tabular}{|c|c|c|c|c|c|c|c|c|c|c|c|}
\hline 4 & 276 & $\begin{array}{r}28 \\
(47.06 \\
\%) \\
\end{array}$ & $\begin{array}{r}6 \\
(5.46 \\
\%) \\
\end{array}$ & $\begin{array}{r}91 \\
(15.43 \\
\%) \\
\end{array}$ & $\begin{array}{r}74 \\
(14.85 \\
\%) \\
\end{array}$ & $\begin{array}{r}6 \\
(7.78 \\
\%) \\
\end{array}$ & $\begin{array}{r}7 \\
(8.98 \% \\
()\end{array}$ & $\begin{array}{r}(0.33 \\
\%)\end{array}$ & $(0.03 \%)$ & $(0.00 \%)$ & $\begin{array}{r}(0.07 \\
\%)\end{array}$ \\
\hline $\begin{array}{c}201 \\
5\end{array}$ & $\begin{array}{r}53524 \\
80\end{array}$ & $\begin{array}{r}24919 \\
95 \\
(46.56 \\
\%)\end{array}$ & $\begin{array}{r}82444 \\
4 \\
(15.40 \\
\%)\end{array}$ & $\begin{array}{r}63542 \\
6 \\
(11.87 \\
\%) \\
\end{array}$ & $\begin{array}{r}52114 \\
3 \\
(9.74 \\
\%) \\
\end{array}$ & $\begin{array}{r}43947 \\
4 \\
(8.21 \\
\%) \\
\end{array}$ & $\begin{array}{r}321290 \\
(6.00 \% \\
)\end{array}$ & $\begin{array}{r}98150 \\
(1.83 \\
\%)\end{array}$ & $\begin{array}{r}4522 \\
(0.08 \%)\end{array}$ & $\begin{array}{r}355 \\
(0.01 \%)\end{array}$ & $\begin{array}{r}1568 \\
1 \\
(0.29 \\
\%) \\
\end{array}$ \\
\hline $\begin{array}{c}201 \\
6\end{array}$ & $\begin{array}{r}55668 \\
76\end{array}$ & $\begin{array}{r}17964 \\
76 \\
(32.27 \\
\%)\end{array}$ & $\begin{array}{r}13730 \\
24 \\
(24.66 \\
\%)\end{array}$ & $\begin{array}{r}97211 \\
4 \\
(17.46 \\
\%)\end{array}$ & $\begin{array}{r}61601 \\
7 \\
(11.07 \\
\%)\end{array}$ & $\begin{array}{r}40342 \\
8 \\
(7.25 \\
\%)\end{array}$ & $\begin{array}{r}145789 \\
(2.62 \% \\
)\end{array}$ & $\begin{array}{r}23902 \\
0 \\
(4.29 \\
\%)\end{array}$ & $\begin{array}{r}7826 \\
(0.14 \%)\end{array}$ & $\begin{array}{r}72 \\
(0.00 \%)\end{array}$ & $\begin{array}{r}1311 \\
0 \\
(0.24 \\
\%)\end{array}$ \\
\hline $\begin{array}{l}\text { CA } \\
\text { GR }\end{array}$ & $\begin{array}{r}14.87 \\
\%\end{array}$ & $\begin{array}{r}18.57 \\
\%\end{array}$ & $\begin{array}{r}10.84 \\
\%\end{array}$ & $\begin{array}{r}11.14 \\
\%\end{array}$ & $\begin{array}{r}18.11 \\
\%\end{array}$ & $\begin{array}{r}20.73 \\
\%\end{array}$ & $\begin{array}{r}15.94 \\
\%\end{array}$ & $\begin{array}{r}18.64 \\
\%\end{array}$ & $6.46 \%$ & & $\begin{array}{r}11.8 \\
3 \%\end{array}$ \\
\hline
\end{tabular}

Source-http://www.trademap.org/stDataSources

The table-V presents on Russia's export with ten member countries of ASEAN. However among all ASEAN members countries five top export destination of Russia are Singapore, Malaysia, Vietnam, Thailand, Philippines. Singapore is the first export destination in comparison to other ASEAN member nations during the period 2001-16. Singapore is the nation with whom Russia has the highest percentage of exports of total exports to ASEAN countries followed by Malaysia, Vietnam, Thailand, Philippines respectively. The compound growth rate of total exports is to Indonesia, Singapore, Myanmar, Thailand, Philippines are 20.73\%,18.57\%, 18.64\%, 18.11\%,15.94\% respectively more than the CAGR of total exports to ASEAN. On the other hand Vietnam and Indonesia purchase a significant proportion of their total military hardware from Russia but the growth of total Russia's export to Vietnam is very low during 2001-16. Russian exports play a much smaller role in Burma, Malaysia, and Thailand still the higher growth rate is give positive sign for present Myanmar and Thailand. Russian defense manufacturers have not sold any weapons to Philippines, Singapore but total exports of Russia to Singapore and Philippines is moderate. So it can be said that there is lot of future prospect of trade relation among Russia and SEA nations.

\section{Resurgent Russia \& Various organizations:-}

Russia is one of the most important actors in the world economy and therefore already integrated in the complex architecture of global economic governance. EU is found to be the largest investor in Russia. Major portion of Russian investment i.e. abroad (60\%) takes place in Europe. Russia's role in East Asia can't be called proactive. No doubt it was determined for comprehensive involvement in the web of regional institutions like APEC, ASEAN dialogue partnership, the Asia-Europe Meeting (ASEM) and the East Asia Summit. The third ASEAN-Russia Summit held in 2016 in Sochi symbolized a new thrust of Russia's relations with regional multilateral structures. However further engagement in multilateralism in East Asia calls for more substance and is facing some challenges both at home and abroad. The APEC Summit in Vladivostok in 2012 was the major breakthrough made by Russia in its attempt to bridge the gap between its economic and political performance in the region. (Koldunova, 2016) Apart from EU, APEC, and ASEAN there are two other economic organizations under study. Those are BRICS \& SAARC. Russia continues to play a key role in the BRICS grouping. Considering Russia's role in the BRICS' grouping's genesis, studying Russia's long term vision on the BRICS can provide useful insights as to where the grouping may be headed.

Table-VI:-Russian Export To Various Organizations And World

\begin{tabular}{|c|c|c|c|c|c|c|c|c|c|c|c|}
\hline $\begin{array}{c}\text { YEA } \\
\mathbf{R}\end{array}$ & $\begin{array}{c}\text { WORL } \\
\text { D }\end{array}$ & ASEAN & & BRICS & & $\begin{array}{c}\text { SAAR } \\
\text { C }\end{array}$ & & $\mathbf{E U}$ & & APEC & \\
\hline 2001 & $\begin{array}{c}9986839 \\
7 \\
\end{array}$ & $\begin{array}{c}119728 \\
6\end{array}$ & $\begin{array}{c}1.20 \\
\%\end{array}$ & $\begin{array}{r}691344 \\
2 \\
\end{array}$ & $\begin{array}{l}6.92 \\
\%\end{array}$ & $\begin{array}{r}12536 \\
97 \\
\end{array}$ & $\begin{array}{c}1.26 \\
\%\end{array}$ & $\begin{array}{r}5438364 \\
4 \\
\end{array}$ & $\begin{array}{c}54.46 \\
\%\end{array}$ & $\begin{array}{r}1511966 \\
2 \\
\end{array}$ & $\begin{array}{r}15.14 \\
\% \\
\end{array}$ \\
\hline 2002 & $\begin{array}{c}1066919 \\
98 \\
\end{array}$ & $\begin{array}{c}151059 \\
7 \\
\end{array}$ & $\begin{array}{c}1.42 \\
\%\end{array}$ & $\begin{array}{r}871768 \\
8 \\
\end{array}$ & $\begin{array}{l}8.17 \\
\%\end{array}$ & $\begin{array}{r}17663 \\
55 \\
\end{array}$ & $\begin{array}{c}1.66 \\
\%\end{array}$ & $\begin{array}{r}5521081 \\
7 \\
\end{array}$ & $\begin{array}{c}51.75 \\
\%\end{array}$ & $\begin{array}{r}1629169 \\
3 \\
\end{array}$ & $\begin{array}{r}15.27 \\
\% \\
\end{array}$ \\
\hline 2003 & 1336556 & 150370 & 1.13 & 112567 & 8.42 & 29042 & 2.17 & 7031622 & 52.61 & 1938788 & 14.51 \\
\hline
\end{tabular}




\begin{tabular}{|c|c|c|c|c|c|c|c|c|c|c|c|}
\hline & 85 & 3 & $\%$ & 47 & $\%$ & 02 & $\%$ & 1 & $\%$ & 3 & $\%$ \\
\hline 2004 & $\begin{array}{c}1816003 \\
79\end{array}$ & $\begin{array}{c}177734 \\
6\end{array}$ & $\begin{array}{c}0.98 \\
\%\end{array}$ & $\begin{array}{r}129847 \\
85 \\
\end{array}$ & $\begin{array}{l}7.15 \\
\%\end{array}$ & $\begin{array}{r}28798 \\
26\end{array}$ & $\begin{array}{c}1.59 \\
\%\end{array}$ & $\begin{array}{r}9491643 \\
5\end{array}$ & $\begin{array}{c}52.27 \\
\%\end{array}$ & $\begin{array}{r}2694681 \\
7\end{array}$ & $\begin{array}{r}14.84 \\
\%\end{array}$ \\
\hline 2005 & $\begin{array}{c}2414516 \\
57\end{array}$ & $\begin{array}{c}215918 \\
8 \\
\end{array}$ & $\begin{array}{c}0.89 \\
\%\end{array}$ & $\begin{array}{r}159926 \\
24 \\
\end{array}$ & $\begin{array}{l}6.62 \\
\%\end{array}$ & $\begin{array}{r}28548 \\
24\end{array}$ & $\begin{array}{c}1.18 \\
\%\end{array}$ & $\begin{array}{r}1391489 \\
75\end{array}$ & $\begin{array}{c}57.63 \\
\%\end{array}$ & $\begin{array}{r}2998406 \\
9\end{array}$ & $\begin{array}{r}12.42 \\
\%\end{array}$ \\
\hline 2006 & $\begin{array}{c}3015506 \\
66\end{array}$ & $\begin{array}{c}195977 \\
9\end{array}$ & $\begin{array}{c}0.65 \\
\%\end{array}$ & $\begin{array}{r}194285 \\
04\end{array}$ & $\begin{array}{l}6.44 \\
\%\end{array}$ & $\begin{array}{r}35774 \\
30\end{array}$ & $\begin{array}{c}1.19 \\
\%\end{array}$ & $\begin{array}{r}1778245 \\
60\end{array}$ & $\begin{array}{c}\mathbf{5 8 . 9 7} \\
\%\end{array}$ & $\begin{array}{r}3583709 \\
5\end{array}$ & $\begin{array}{r}11.88 \\
\%\end{array}$ \\
\hline 2007 & $\begin{array}{c}3522663 \\
99\end{array}$ & $\begin{array}{c}256329 \\
6 \\
\end{array}$ & $\begin{array}{c}0.73 \\
\%\end{array}$ & $\begin{array}{r}193443 \\
37 \\
\end{array}$ & $\begin{array}{l}5.49 \\
\%\end{array}$ & $\begin{array}{r}36130 \\
28 \\
\end{array}$ & $\begin{array}{c}1.03 \\
\%\end{array}$ & $\begin{array}{r}1687372 \\
65 \\
\end{array}$ & $\begin{array}{c}47.90 \\
\%\end{array}$ & $\begin{array}{r}4063091 \\
0 \\
\end{array}$ & $\begin{array}{r}11.53 \\
\%\end{array}$ \\
\hline 2008 & $\begin{array}{c}4679939 \\
55\end{array}$ & $\begin{array}{c}437133 \\
2\end{array}$ & $\begin{array}{c}0.93 \\
\%\end{array}$ & $\begin{array}{r}284593 \\
26\end{array}$ & $\begin{array}{l}6.08 \\
\%\end{array}$ & $\begin{array}{r}61120 \\
62\end{array}$ & $\begin{array}{c}1.31 \\
\%\end{array}$ & $\begin{array}{r}2674688 \\
91\end{array}$ & $\begin{array}{c}57.15 \\
\%\end{array}$ & $\begin{array}{r}6079954 \\
1\end{array}$ & $\begin{array}{r}12.99 \\
\%\end{array}$ \\
\hline 2009 & $\begin{array}{c}3017960 \\
59\end{array}$ & $\begin{array}{c}360752 \\
5\end{array}$ & $\begin{array}{c}1.20 \\
\%\end{array}$ & $\begin{array}{r}238842 \\
84\end{array}$ & $\begin{array}{l}7.91 \\
\%\end{array}$ & $\begin{array}{r}66405 \\
99\end{array}$ & $\begin{array}{c}2.20 \\
\%\end{array}$ & $\begin{array}{r}1597848 \\
60\end{array}$ & $\begin{array}{c}\mathbf{5 2 . 9 4} \\
\%\end{array}$ & $\begin{array}{r}4512832 \\
9\end{array}$ & $\begin{array}{r}14.95 \\
\%\end{array}$ \\
\hline 2010 & $\begin{array}{c}3970675 \\
21\end{array}$ & $\begin{array}{c}651360 \\
7\end{array}$ & $\begin{array}{l}1.64 \\
\%\end{array}$ & $\begin{array}{r}269580 \\
55\end{array}$ & $\begin{array}{l}6.79 \\
\%\end{array}$ & $\begin{array}{r}63265 \\
94\end{array}$ & $\begin{array}{c}1.59 \\
\%\end{array}$ & $\begin{array}{r}1846707 \\
34\end{array}$ & $\begin{array}{c}46.51 \\
\%\end{array}$ & $\begin{array}{r}6514952 \\
8\end{array}$ & $\begin{array}{r}16.41 \\
\%\end{array}$ \\
\hline 2011 & $\begin{array}{c}5169926 \\
18\end{array}$ & $\begin{array}{c}785734 \\
2\end{array}$ & $\begin{array}{l}1.64 \\
\%\end{array}$ & $\begin{array}{r}415752 \\
13\end{array}$ & $\begin{array}{l}8.04 \\
\%\end{array}$ & $\begin{array}{r}59617 \\
98\end{array}$ & $\begin{array}{c}1.15 \\
\%\end{array}$ & $\begin{array}{r}2305441 \\
02\end{array}$ & $\begin{array}{c}44.59 \\
\%\end{array}$ & $\begin{array}{r}8989373 \\
3\end{array}$ & $\begin{array}{r}17.39 \\
\%\end{array}$ \\
\hline 2012 & $\begin{array}{c}5247664 \\
21\end{array}$ & $\begin{array}{l}730548 \\
4\end{array}$ & $\begin{array}{l}1.39 \\
\%\end{array}$ & $\begin{array}{l}459171 \\
35\end{array}$ & $\begin{array}{l}8.75 \\
\%\end{array}$ & $\begin{array}{r}91390 \\
89\end{array}$ & $\begin{array}{c}1.74 \\
\%\end{array}$ & $\begin{array}{r}2457097 \\
45\end{array}$ & $\begin{array}{c}46.82 \\
\%\end{array}$ & $\begin{array}{r}9149091 \\
8\end{array}$ & $\begin{array}{r}17.43 \\
\%\end{array}$ \\
\hline 2013 & $\begin{array}{l}5272659 \\
19\end{array}$ & $\begin{array}{l}849089 \\
5\end{array}$ & $\begin{array}{l}1.61 \\
\%\end{array}$ & $\begin{array}{r}448789 \\
69\end{array}$ & $\begin{array}{c}8.51 \\
\%\end{array}$ & $\begin{array}{r}84027 \\
78\end{array}$ & $\begin{array}{c}1.59 \\
\%\end{array}$ & $\begin{array}{r}2412460 \\
56\end{array}$ & $\begin{array}{c}45.75 \\
\%\end{array}$ & $\begin{array}{r}9935656 \\
1\end{array}$ & $\begin{array}{r}18.84 \\
\%\end{array}$ \\
\hline 2014 & $\begin{array}{c}4978335 \\
29 \\
\end{array}$ & $\begin{array}{l}117962 \\
76\end{array}$ & $\begin{array}{l}2.37 \\
\%\end{array}$ & $\begin{array}{r}443855 \\
35 \\
\end{array}$ & $\begin{array}{c}8.92 \\
\%\end{array}$ & $\begin{array}{r}53096 \\
24\end{array}$ & $\begin{array}{c}1.07 \\
\%\end{array}$ & $\begin{array}{r}2244091 \\
07 \\
\end{array}$ & $\begin{array}{c}45.08 \\
\%\end{array}$ & $\begin{array}{r}1046549 \\
44 \\
\end{array}$ & $\begin{array}{r}21.02 \\
\%\end{array}$ \\
\hline 2015 & $\begin{array}{c}3439076 \\
52\end{array}$ & $\begin{array}{c}535248 \\
0\end{array}$ & $\begin{array}{l}1.56 \\
\%\end{array}$ & $\begin{array}{r}350821 \\
29\end{array}$ & $\begin{array}{c}10.20 \\
\%\end{array}$ & $\begin{array}{r}53822 \\
35\end{array}$ & $\begin{array}{c}1.57 \\
\%\end{array}$ & $\begin{array}{r}1367798 \\
78\end{array}$ & $\begin{array}{c}39.77 \\
\%\end{array}$ & $\begin{array}{r}7527391 \\
2\end{array}$ & $\begin{array}{r}21.89 \\
\%\end{array}$ \\
\hline 2016 & $\begin{array}{c}2854910 \\
52\end{array}$ & $\begin{array}{c}556687 \\
6\end{array}$ & $\begin{array}{l}1.95 \\
\%\end{array}$ & $\begin{array}{r}353161 \\
92\end{array}$ & $\begin{array}{c}12.37 \\
\%\end{array}$ & $\begin{array}{r}64820 \\
61\end{array}$ & $\begin{array}{c}2.27 \\
\%\end{array}$ & $\begin{array}{r}1306171 \\
92\end{array}$ & $\begin{array}{c}45.75 \\
\%\end{array}$ & $\begin{array}{r}6747508 \\
0\end{array}$ & $\begin{array}{r}23.63 \\
\%\end{array}$ \\
\hline $\begin{array}{c}\text { CAG } \\
\text { R }\end{array}$ & $9.7 \%$ & $14.87 \%$ & & $12.62 \%$ & & $\begin{array}{r}10.49 \\
\%\end{array}$ & & $7.8 \%$ & & $13.5 \%$ & \\
\hline
\end{tabular}

Source-http://www.trademap.org/stDataSources

The above table gives the value of Russia's export to five organizations and the relative percentage in comparison with the world as well as the Compound Annual Growth Rate during 2001-16. Here the five economic organizations have been taken for comparison. They are ASEAN, BRICS, SAARC, EU and APEC. EU is the top export destination of Russia and APEC in second position is depicted by the table. Russia's export to the ASEAN relative to total exports to the world has increased from $1.20 \%$ in 2001 to $2.37 \%$ in 2014 and it ha s declined in recent years to $1.95 \%$ in 2016.The percentage of Russia's export to the BRICS in relation to total export has increased from $6.92 \%$ in 2001 to $12.37 \%$ in 2016.The status of Russia's export to the SAARC in comparison with total export has increased from $1.26 \%$ in 2001 to $2.27 \%$ in 2016 . The percentage of Russia's export to the APEC in relation to total export has increased from $15.16 \%$ in 2001 to $23.63 \%$ in 2016. It is clear that APEC as export destination of Russia played significant role in comparison with other organizations. The proportion of Russia's export to the EU relative to total export has increased from $54.46 \%$ in 2001 to $58.97 \%$ in 2006 and it ha s declined in recent years to $45.75 \%$ in 2016.

This table also reflects Compound Annual Growth Rate (CAGR) of exports of Russia to all organizations. The CAGR of Russia's export to ASEAN is $14.87 \%$, this is maximum in comparison with other groups as well as exports to world. The CAGR of Russia with world is 9.7\%. Though Russia is a minor player in Southeast Asia in comparison to other economic organizations and apart from natural resources, energy technology and arms sales, there seems scope for expansion in Russia-ASEAN trade.

India as the gateway of Russian trade with SEA Nations:-

The potency of the Russian economic presence in Southeast Asia lies in oil and gas, nuclear energy, and military technology. Singapore and Malaysia buy Russian oil and Indonesia is also involved in several energy projects, but 
again it is Vietnam that is Russia's chief oil and gas partner, with projects in both Vietnam and Russia. During the time of Atal Bihari Vajpayee as the PM of India, Russia's Foreign minister Ivanov was looking for economic and security relations across a vast region extending from the oil-rich Central Asian republics to South-East Asia in a move reminiscent of the Cold War era. It was also noted that Russia remains a close Indian ally and its principal weapon supplier. It is apparently going to revitalize the five-year old proposal for a Moscow-Delhi- Beijing axis against US ascendancy to ensure a multi-polar world.(Bedi,2003)Russian business in the sector military product is impressive in SEA region in $20^{\text {th }}$ century. Especially Indonesia, Malaysia purchased many of the fighter jets from Russia. India's strategic and business interests in South-east Asia are increased to buy the Russian fighters, it is expected to provide training and servicing to the Royal Malaysian Air Force by India. Malaysia bought Russian MiG 29 fighters and Mi 17 helicopters to give importance to India's experience with these aircraft. In this way India has acted as a gateway for Russian arms sales to South-east Asia. Here we can say that there will be prospects for India-Russia mutual business and strategic interest in SEA region and will be gainer profit in this process. In June 2015 two states Russia and Myanmar signed a memorandum of understanding to cooperate in nuclear technology for peaceful purposes. The Russian state corporation is looking for potential investment opportunities in the Southeast Asian region, and is offering comprehensive nuclear technology and experience. Rosatom is a state corporation in Russia, established in 2007 , the regulatory body of the Russian nuclear complex. It is headquartered in Moscow. It opens its regional headquarters in Singapore in 2012, and has since organized a number of visits to Russian nuclear power plants. The company is building two nuclear power units in Vietnam and won a tender for the preliminary design of a 10 megawatt reactor in Indonesia. Regionally the company has signed cooperation agreements with Thailand, Myanmar, Laos, and Cambodia for nuclear technology.(Shin,2016) Russian weapons are still the hottest commodity on Southeast Asian markets especially Vietnam has historically been and still remains the region's largest buyer of Russian arms. Russia is a significant player in the global arms market and the second arms exporter after US. Between 2012 and 2015, India will once again become the number one importer ( $\$ 14.3$ billion), followed by Venezuela ( $\$ 3.2$ billion) instead of Algeria. Vietnam will rank third, with imports of $\$ 3.2$ billion. In recent years Russia approved about $\$ 7$ billion worth of export loans under weapons contracts. This has enabled Rosoboron export to sign new deals with Myanmar, Malaysia, Indonesia, Sri Lanka and Vietnam. Moscow is determined to keep its share of the Indian defence market and to retain its status as the world's second-largest defence exporter. The main partner in the region is a traditional friend of Russia - Venezuela. It is now the second biggest purchaser of Russian arms, after India that Russia needs to press ahead. The Sukhoi Su-57 fifth generation fighter and the BrahMos supersonic multiple usage cruise missile are the most visible outcomes of joint venture production with India. From 2012 to 2016, Russia supplied 68 per cent of India's arms import, as per the survey by Stockholm International Peace Research Institute (SIPRI) - an international think-tank that researches on conflict, armaments, arms control and disarmament. In the same period, the US supplied 14 per cent of arms to India, followed by Israel (7.2 per cent). The SIPRI report also foresees Russia maintaining the lead in supplying weapons to India - which has emerged as the biggest importer of major arms with overseas procurements exceeding that of China and Pakistan. India offered Laos military assistance in the form of supply of parachutes and military trucks. New Delhi also agreed to help refurbish the Vietnamese air force, providing MiG -21s with new avionics and radar to support Russia's latest missiles, including the R-77 AMRAAMSKI and the R-27 dogfight, and to help Vietnam set up a domestic arms industry to manufacture small and medium weapons and certain kinds of ordnance Not only in arms and weapons but in the field of petroleum export to SEA, Russia is taking the help of India. Russian oil major Rosneft's has recently acquired Essar India and its massive investment plans in the Indian market may make a revolution in the Indian oil industry and positive impact on Indian economy. The India's Oil market is expected to expand dramatically in the period ahead commensurate with the economy's potential for high growth. The acquisition places in Rosneft's hands India's largest network of private petrol pumps, the country's second-largest refinery, a 1,000-MW power plant along with the Vadinar port and oil terminal. Rosneft looks upon the India business as a starting point to expand in the Asia-Pacific region by supplying fuels to Indonesia, Vietnam, and the Philippines.

\section{Conclusion:-}

The relative importance of ASEAN as a trade partner with India and Russia has been strengthened over last sixteen years. Both country's exports to ASEAN as well as imports from ASEAN have grown at a satisfactory rate i.e., $16.39 \%$ and $17.74 \%$ compound annual growth rate of exports and imports respectively in case of India and $14.87 \%$ and $20.05 \%$ in case of Russia. India's trade relation with various regional organizations such as ASEAN, BRICS, SAARC, EU and APEC further highlights that India's exports to ASEAN has highest growth rate compared to other organizations, though APEC and EU are more significant export destination in terms of value of exports. Similar trend has been observed with regard to Russia's trade relation with ASEAN. Though Russia is a minor player in 
ASEAN region, yet it has improved over the years during period under study and there is an increasing scope for the expansion of trade. An aggregate analysis of India's exports to ASEAN and Russia's exports to ASEAN exhibit the importance of ASEAN for both India and Russia's trade. The two traditional partners besides collaborating both economically and politically are turning their attention to ASEAN more and more in the advancing years of globalization.

\section{References:-}

1. Wayfarer. (2007). Indo-Asian relations in the upswing. Merinews: People to People. Retrieved from http://www.merinews.com/article/indo-asean-relations-on-the-upswing (accessed on 26 April 2010).

2. Baten, Jörg (2016). A History of the Global Economy. From 1500 to the Present. Cambridge University Press. p. 282.

3. Master plan on ASEAN connectivity ( 2010) www.asean.org.

4. Ministry of External Affairs (2014) Government of India, Opening Statement by Prime Minister at the $12^{\text {th }}$ India-ASEAN Summit, Nay Pyi Taw, Myanmar, http://www.mea.gov.in/Speeches-Statements.htm? (Accessed on 9th September 2016)

5. Sajjanhar,Ashok (2016) 2 Years On, Has Modi's 'Act East' Policy Made a Difference for India?, The Diplomat, http://thediplomat.com.

6. KhngHeng ,Russell Hiang-, Wei-Yen, Denis Hew .(2004)Regional Outlook: Southeast Asia 2004-2005, Institute of Southeast Asian Studies, 2004.

7. Choudhary, Sarika (2013) India and ASEAN Trade: An Overview, International Journal Of Social Science \& Interdisciplinary Research, Vol.2 (2), February.

8. Jha, pankajkumar,(2011) India's defence diplomacy in South east Asia, Vol 5. No 1. January, Journal of Defence Studies)

9. Chase, K. A., (2006) Trading Blocs. s.l.: The University of Michigan Press.

10. India Today. (2012).Reconsider relations with the European Union",18 May

11. Torres, (2013)Southeastern Promises?: An Appraisal of the Russia-ASEAN Economic Partnership, CSIS Center for Strategic and International Studies, AUG 7.)

12. Tsvetov, Anton (2016) Russia and ASEAN: in Search of Economic Synergy and Political Consensus, Media and Government Relations Manager at the Russian International Affairs Council 10 JUNE, RIAC.

13. Mirkasymov, Bakhtiyar. (2007). Russian policy to Asian regionalism. Asia-Pacific Review, 14(2), 82-96.).

14. Martynova, Elena S. (2014) Strengthening of Cooperation Between Russia and ASEAN: Rhetoric or Reality? Asian Politics \& Policy-Volume 6, Number 3.

15. Nikolas Gvosdev (2016), With Putin's ASEAN Outreach, Russia Sets Sights on Southeast Asia, May 24.

16. Koldunova, Ekaterina, (2016) 17 August, Can Russia be a leader in East Asian economic integration? MGIMO University, http://www.eastasiaforum.org.

17. Bedi ,Rahul, (2003)Now it's Russia's turn to look east, Asia Times , \#21-JRL 7227,russialist.org/archives.

18. Shin, Aung (2016) Russia and Myanmar to establish working body for nuclear technology,www.mmtimes.com, accessed on September,2017). 